\title{
Ship impacts on the marine atmosphere: insights into the contribution of shipping emissions to the properties of marine aerosol and clouds
}

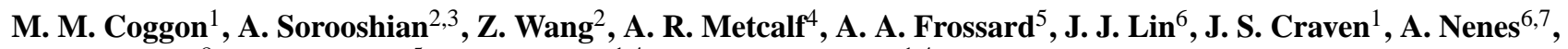

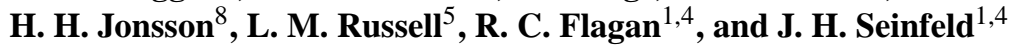 \\ ${ }^{1}$ Department of Chemical Engineering, California Institute of Technology, Pasadena, CA, USA \\ ${ }^{2}$ Department of Chemical and Environmental Engineering, University of Arizona, Tucson, AZ, USA \\ ${ }^{3}$ Department of Atmospheric Sciences, University of Arizona, Tucson, AZ, USA \\ ${ }^{4}$ Department of Environmental Science and Engineering, California Institute of Technology, Pasadena, CA, USA \\ ${ }^{5}$ SCRIPPS Institution of Oceanography, University of California, San Diego, CA, USA \\ ${ }^{6}$ School of Earth and Atmospheric Sciences, Georgia Inst. of Technology, Atlanta, GA, USA \\ ${ }^{7}$ School of Chemical and Biomolecular Engineering, Georgia Institute of Technology, Atlanta, GA, USA \\ ${ }^{8}$ Naval Postgraduate School, Monterey, CA, USA \\ Correspondence to: J. H. Seinfeld (seinfeld@caltech.edu)
}

Received: 22 May 2012 - Published in Atmos. Chem. Phys. Discuss.: 7 June 2012

Revised: 1 September 2012 - Accepted: 3 September 2012 - Published: 20 September 2012

\begin{abstract}
We report properties of marine aerosol and clouds measured in the shipping lanes between Monterey Bay and San Francisco off the coast of Central California. Using a suite of aerosol instrumentation onboard the CIRPAS Twin Otter aircraft, these measurements represent a unique set of data contrasting the properties of clean and ship-impacted marine air masses in dry aerosol and cloud droplet residuals. Below-cloud aerosol exhibited average mass and number concentrations of $2 \mu \mathrm{g} \mathrm{m}^{-3}$ and $510 \mathrm{~cm}^{-3}$, respectively, which are consistent with previous studies performed off the coast of California. Enhancements in vanadium and cloud droplet number concentrations are observed concurrently with a decrease in cloud water $\mathrm{pH}$, suggesting that periods of high aerosol loading are primarily linked to increased ship influence. Mass spectra from a compact time-of-flight Aerodyne aerosol mass spectrometer reveal an enhancement in the fraction of organic at $m / z 42\left(f_{42}\right)$ and $99\left(f_{99}\right)$ in ship-impacted clouds. These ions are well correlated to each other $\left(R^{2}>0.64\right)$ both in and out of cloud and constitute $14 \%\left(f_{44}\right)$ and $3 \%\left(f_{99}\right)$ of organic mass during periods of enhanced sulfate. High-resolution mass spectral analysis of these masses from ship measurements suggests that the ions responsible for this variation were oxidized, pos-
\end{abstract}

sibly due to cloud processing. We propose that the organic fractions of these ions be used as a metric for determining the extent to which cloud-processed ship emissions impact the marine atmosphere where $\left(f_{42}>0.15 ; f_{99}>0.04\right)$ would imply heavy influence from shipping emissions, $\left(0.05<f_{42}<0.15 ; 0.01<f_{99}<0.04\right)$ would imply moderate, but persistent, influences from ships, and $\left(f_{42}<0.05\right.$; $\left.f_{99}<0.01\right)$ would imply clean, non-ship-influenced air.

\section{Introduction}

Ship exhaust is estimated to account for 14 and $16 \%$ of global $\mathrm{NO}_{\mathrm{x}}$ and $\mathrm{SO}_{\mathrm{x}}$ emissions, respectively (Corbett and Fischbeck, 1997). Models show that ship emissions also contribute $1.67 \mathrm{Tg} \mathrm{yr}^{-1}$ to global particulate matter, which is nearly equivalent to current estimates of particulate matter emitted by all on-road vehicles (Eyring et al., 2005; Yan et al., 2011). Because many shipping lanes are located along coastal regions where marine stratocumuli persist, ship emissions have the potential to directly affect cloud microphysics. Studies of cargo ship exhaust/cloud interactions have shown distinct cloud responses to these perturbations (e.g., Coakley 
et al., 1987; Ackerman et al., 1995; Frick and Hoppel, 2000; Durkee et al., 2000; Hudson et al., 2000; Noone et al., 2000; Lu et al., 2009; Christensen and Stephens, 2011). Satellite imagery shows that ship tracks can exist hours after initial emission (Coakley et al., 1987; Durkee et al., 2000; Christensen and Stephens, 2011) and therefore have the potential to exert a significant effect on local radiative fluxes.

Ship emissions mix with marine aerosol and subsequently with cloud droplets, however the extent of this effect is not well established. Marine aerosol is a complex mixture of natural and anthropogenic sources, and thus the signature from shipping emissions is difficult to detect. Natural marine aerosol comprises particles resulting from seaspray (e.g., $\mathrm{NaCl}, \mathrm{KCl}$, organics), marine biological activity (e.g., dimethylsulfide and subsequent oxidation products), and those from continental origins (e.g., dust, secondary products from biogenic oxidation). Anthropogenic sources include ship emissions, continental pollution, and biomass burning. Sea-salt typically dominates the super micrometer aerosol $\left(D_{\mathrm{p}}>1 \mu \mathrm{m}\right)$, whereas organics, sulfate, and ammonium from natural and anthropogenic sources constitute a large portion of mass in the submicrometer regime $\left(D_{\mathrm{p}} \leq 1 \mu \mathrm{m}\right)$ (Cunningham and Zoller, 1981; McInnes et al., 1996).

With its location along busy shipping lanes and near heavily populated areas, the California coastal zone is an especially advantageous region to evaluate the anthropogenic contribution to marine aerosol and cloud condensation nuclei $(\mathrm{CCN})$. Table 1 summarizes studies conducted in the vicinity of the California coastal zone on marine aerosol and cloud droplets. Important studies by Hegg et al. (2008, 2009, 2010) have utilized source apportionment models to attribute size-resolved hygroscopicity, light scattering coefficient, and $\mathrm{CCN}$ activity of marine aerosol to natural and anthropogenic sources. They estimated that $50 \%$ of the measured CCN concentrations and $57 \%$ of the light-scattering coefficient of marine aerosol in the California coastal region originated from anthropogenic sources. Though anthropogenic signatures contribute significantly to measured aerosol properties, the extent to which ship emissions contribute to this signal remains uncertain.

Few studies along the California coast have investigated marine aerosol and cloud properties simultaneously (Table 1). In this study, we utilize state-of-the-art aerosol measurements to build upon the knowledge of marine aerosol and cloud properties, with special attention to the contribution from ship emissions.

\section{Methodology}

\subsection{Field mission description}

From July-August 2011, the Eastern Pacific Emitted Aerosol Cloud Experiment 2011 (E-PEACE) was operated out of the
Center for Interdisciplinary Remotely-Piloted Aircraft Studies (CIRPAS) in Marina, CA (Russell et al., 2012). The purpose of the field mission was to study the effect of ship emissions, sea-salt and organic aerosol on Eastern Pacific marine stratocumulus commonly found off the coast of Central California. Thirty flights were conducted by the CIRPAS Twin Otter aircraft to probe the emissions of cargo and tanker ships and their effects on marine stratocumulus. The focus of this study is a set of measurements made during twenty-six flights conducted in a sampling region between San Francisco and Monterey Bay (Fig. 1). Four additional flights were performed outside of this sampling region and are analyzed in Sect. 4.1 to compare aerosol properties during cloudy and clear conditions, however a more extensive analysis of these flights will be forthcoming. In addition to sampling direct ship emissions, measurements of aerosol and cloud properties were made below, within, and above cloud during each flight. Simultaneous measurements of marine aerosol properties were conducted onboard the R/V Point Sur. Averaged measurements made outside direct ship fumigation were taken to reflect the variation of marine aerosol and cloud properties over the course of the campaign.

\subsection{Aerosol and cloud droplet measurement methodology}

Cloud and aerosol properties were measured by ship and aircraft using a suite of aerosol instruments (Table 2). A detailed description of the instrumentation used in this study can be found in the Appendix. Cloud droplet residuals were measured downstream of a counterflow virtual impactor (CVI) inlet with a cut size of $11 \mu \mathrm{m}$ (Shingler et al., 2012).

In the following discussion, we report cloud residual mass concentrations measured behind the CVI inlet. Despite the improved CVI design that can accommodate high sample flow and thus reduce the need for large counterflow and dilution (Shingler et al., 2012), uncertainties remain in total mass and number concentrations that are common among all CVI inlets. Primarily, the transmission efficiency (TE) of the CVI is a function of several parameters, including aircraft speed, sample-flow dilution, and particle diameter. In addition, the instrument is characterized by a cut size that restricts the smallest particle that can be sampled; thus, the cloud residual mass concentrations reported in this study (Table 3) are less than the total cloud residual mass. However, there are relative differences between periods of low and high concentration that suggest a qualitative difference between flights.

An altitude-dependent, zig-zag aircraft sampling pattern was utilized to measure unperturbed and perturbed air masses. Upon locating a ship, the Twin Otter sampled below, within and above cloud in close proximity to the ship's plume. While in cloud, measurements were made behind the CVI, thus sampling only cloud droplet residuals. Measurements made out of cloud were sampled through the main sub-isokinetic aerosol inlet. The main inlet is designed to 
Table 1. Previous studies on the properties of marine aerosol over the Northeastern Pacific Ocean. Footnotes define instrument abbreviations.

\begin{tabular}{|c|c|c|c|c|c|c|c|c|c|c|}
\hline Author & $\begin{array}{l}\text { Research } \\
\text { Location }\end{array}$ & Instruments & $\begin{array}{l}\text { Type of } \\
\text { Mission }\end{array}$ & $\begin{array}{l}\text { Sources } \\
\text { Sampled }\end{array}$ & $\begin{array}{l}\mathrm{CCN} \\
\text { Properties }\end{array}$ & Hygroscopicty & $\begin{array}{l}\text { Size } \\
\text { Properties }\end{array}$ & $\begin{array}{l}\text { Chemical } \\
\text { Properties }\end{array}$ & Species Analyzed & Summary \\
\hline $\begin{array}{l}\text { Hegg et al. } \\
\text { (1996) }\end{array}$ & $\begin{array}{l}\text { Pacific } \\
\text { Coast }\end{array}$ & $\begin{array}{l}\text { nephelometer } \\
\text { PCASP, SMPS, } \\
\text { DNH }\end{array}$ & Aircraft & $\begin{array}{l}\text { Dry } \\
\text { Aerosol }\end{array}$ & - & yes & - & - & - & $\begin{array}{l}\text { Authors report the optical and hygroscopic properties } \\
\text { of marine aerosol in the vicinity of the California coast. } \\
\text { The hygroscopic growth factor was shown to be } 1.7 \\
\text { while the ratio of backscatter to total scattering was } \\
\text { found to be } 0.13 \text {. }\end{array}$ \\
\hline $\begin{array}{l}\text { McInnes et al. } \\
\text { (1996) }\end{array}$ & E. Pacific & $\begin{array}{l}\text { Filter Sampling } \\
\text { and off-line analy- } \\
\text { tical chemistry }\end{array}$ & $\begin{array}{l}\text { Ground, } \\
\text { Ship }\end{array}$ & $\begin{array}{l}\text { Dry } \\
\text { Aerosol }\end{array}$ & - & - & - & yes & $\begin{array}{l}\text { sea salt ions, } \\
\text { sulfate, } \\
\text { ammonium, } \\
\text { water }\end{array}$ & $\begin{array}{l}\text { This study investigated the composition of } \\
\text { sub-micrometer aerosol. Gravimetric measurements } \\
\text { showed that a significant amount of mass }(0-76 \%) \\
\text { was unaccounted for in filter measurements. Water } \\
\text { uptake on the filter samples made up } 29 \% \text { of the } \\
\text { mass and the remaining mass was likely to be } \\
\text { organic in nature. }\end{array}$ \\
\hline $\begin{array}{l}\text { Phinney et al. } \\
\text { (2006) }\end{array}$ & $\begin{array}{l}\text { N.E. } \\
\text { Pacific }\end{array}$ & $\begin{array}{l}\text { SMPS, PCASP, } \\
\text { MOUDI, AMS, } \\
\text { GC }\end{array}$ & Ship & $\begin{array}{l}\text { Dry } \\
\text { Aerosol }\end{array}$ & - & - & yes & yes & $\begin{array}{l}\text { MSA, sulfate, } \\
\text { organics, nitrate, } \\
\text { ammonium, } \\
\text { sea salt }\end{array}$ & $\begin{array}{l}\text { Marine aerosol off the coast of British Columbia was } \\
\text { measured for size and composition. MSA was found } \\
\text { to be an order magnitude higher than previously } \\
\text { observed in the N.E. Pacific. AMS organic spectra } \\
\text { showed that ship emissions may play a role in } \\
\text { contributing to the organic signature of marine } \\
\text { aerosol. }\end{array}$ \\
\hline $\begin{array}{l}\text { Straub et al. } \\
(2007)\end{array}$ & $\begin{array}{l}\text { California } \\
\text { Coast }\end{array}$ & $\begin{array}{l}\text { Cloud water } \\
\text { collector inlet } \\
\text { and off-line analy- } \\
\text { tical chemistry, } \\
\text { FSSP, PCASP, } \\
\text { PVM (LWC) }\end{array}$ & Aircraft & $\begin{array}{l}\text { Cloud } \\
\text { Particles }\end{array}$ & - & - & - & yes & $\begin{array}{l}\text { TOC, inorganic } \\
\text { ions, sulfate, } \\
\text { nitrate, hydrogen } \\
\text { peroxide, } \\
\text { formaldehyde }\end{array}$ & $\begin{array}{l}\text { Cloud water off the coast of California was analyzed } \\
\text { for ionic, TOC, trace ion, soluble organics and } \\
\text { formaldehyde concentrations. The measurements } \\
\text { represent a unique compilation of remote marine } \\
\text { cloud water chemistry. }\end{array}$ \\
\hline $\begin{array}{l}\text { Sorooshian et al. } \\
\text { (2007a) }\end{array}$ & $\begin{array}{l}\text { California } \\
\text { Coast }\end{array}$ & $\begin{array}{l}\text { PILS, LWC, } \\
\text { CVI }\end{array}$ & Aircraft & $\begin{array}{l}\text { Cloud } \\
\text { Particles }\end{array}$ & - & - & - & yes & oxalate, sulfate & $\begin{array}{l}\text { Oxalate: } \mathrm{SO}_{4} \text { measurements tended to increase with } \\
\text { altitude, suggesting that cloud processing of below- } \\
\text { cloud aerosols generated a higher fraction of oxalate. } \\
\text { LES simulations showed that particles above cloud } \\
\text { were likely generated due to cloud evaporation; thus, } \\
\text { the high fractions of oxalate observed above cloud } \\
\text { were partially due to cloud processing. }\end{array}$ \\
\hline $\begin{array}{l}\text { Hegg et al. } \\
\text { (2008) }\end{array}$ & $\begin{array}{l}\text { California } \\
\text { Coast }\end{array}$ & $\begin{array}{l}\text { Filter Sampling } \\
\text { and off-line analy- } \\
\text { tical chemistry, } \\
\text { AHS, Light- } \\
\text { scattering humi- } \\
\text { digraph, PSAP }\end{array}$ & Aircraft & $\begin{array}{l}\text { Dry } \\
\text { Aerosol }\end{array}$ & - & yes & - & yes & $\begin{array}{l}\text { organics, inor- } \\
\text { ganic ions, BC, } \\
\text { sulfate, lead }\end{array}$ & $\begin{array}{l}\text { Aerosol hygroscopicity was observed to increase with } \\
\text { altitude. Given that the MBL is a well mixed system, } \\
\text { changes in aerosol properties with altitude plausibly } \\
\text { resulted from oxidation of organic films. No evidence } \\
\text { for the accumulation of inorganics was observed. }\end{array}$ \\
\hline $\begin{array}{l}\text { Hegg et al. } \\
(2009)\end{array}$ & $\begin{array}{l}\text { California } \\
\text { Coast }\end{array}$ & $\begin{array}{l}\text { Filter Sampling } \\
\text { and off-line analy- } \\
\text { tical chemistry, } \\
\text { AHS, PSAP, } \\
\text { CCN, PCASP }\end{array}$ & Aircraft & $\begin{array}{l}\text { Dry } \\
\text { Aerosol }\end{array}$ & yes & - & yes & yes & $\begin{array}{l}\text { organics, inor- } \\
\text { ganic ions, BC, } \\
\text { sulfate, lead }\end{array}$ & $\begin{array}{l}\mathrm{CCN} \text { measurements off the coast of California are } \\
\text { attributed to natural and anthropogenic sources using } \\
\text { receptor modeling. Roughly } 50 \% \text { of the samples } \\
\text { measured in the study were anthropogenic in nature. }\end{array}$ \\
\hline $\begin{array}{l}\text { Hersey et al. } \\
(2009)\end{array}$ & $\begin{array}{l}\text { California } \\
\text { Coast }\end{array}$ & AMS, DASH-SP & Aircraft & $\begin{array}{l}\text { Dry } \\
\text { Aerosol }\end{array}$ & - & yes & - & - & $\begin{array}{l}\text { organics, } \\
\text { sulfate }\end{array}$ & $\begin{array}{l}\text { DASH-SP and AMS measurements are coupled to } \\
\text { characterize the chemical dependence of aerosol } \\
\text { growth factors. It was found that higher organic } \\
\text { fractions yielded lower growth factors at high RH. } \\
\text { High organic fractions are correlated with continental } \\
\text { sources from back trajectory modeling. }\end{array}$ \\
\hline $\begin{array}{l}\text { Sorooshian et al. } \\
\text { (2009) }\end{array}$ & $\begin{array}{l}\text { California } \\
\text { Coast }\end{array}$ & $\begin{array}{l}\text { PILS-IC, LWC, } \\
\text { FSSP, SMPS, } \\
\text { CCN, DASH-SP }\end{array}$ & $\begin{array}{l}\text { Aircraft, } \\
\text { ground, } \\
\text { satellite }\end{array}$ & $\begin{array}{l}\text { Aerosol, } \\
\text { Clouds }\end{array}$ & yes & yes & yes & yes & DEA, MSA & $\begin{array}{l}\text { The link between chlorophyll } a \text { concentrations and the } \\
\text { fraction of MSA and DEA in aerosol suggests that } \\
\text { ocean biota have significant influence over marine } \\
\text { aerosol properties including CCN and hygroscopicity. } \\
\text { A link between cloud properties and chlorophyll } a \\
\text { is not shown as cloud properties were heavily } \\
\text { influenced by meteorological conditions. }\end{array}$ \\
\hline $\begin{array}{l}\text { Hegg et al. } \\
\text { (2010) }\end{array}$ & $\begin{array}{l}\text { California } \\
\text { Coast }\end{array}$ & $\begin{array}{l}\text { Filter Sampling } \\
\text { and off-line analy- } \\
\text { tical chemistry, } \\
\text { AHS, PSAP, } \\
\text { CCN, PCASP }\end{array}$ & Aircraft & $\begin{array}{l}\text { Dry } \\
\text { Aerosol }\end{array}$ & yes & yes & yes & yes & $\begin{array}{l}\text { organics, inor- } \\
\text { ganic ions, BC, } \\
\text { sulfate, lead }\end{array}$ & $\begin{array}{l}\text { A receptor based model is used to investigate the } \\
\text { extent of anthropogenic sources on } \mathrm{CCN} \text { in the } \\
\text { marine environment. The authors report that } 63-74 \% \\
\text { of the aerosols are anthropogenic in nature. }\end{array}$ \\
\hline $\begin{array}{l}\text { Langley et al. } \\
\text { (2010) }\end{array}$ & $\begin{array}{l}\text { N.E. } \\
\text { Pacific }\end{array}$ & $\begin{array}{l}\text { AMS, SMPS, } \\
\mathrm{CCN} \text {, gas } \\
\text { phase } \mathrm{SO}_{2}\end{array}$ & Ship & $\begin{array}{l}\text { Dry } \\
\text { Aerosol }\end{array}$ & yes & - & yes & yes & $\begin{array}{l}\text { MSA, } \mathrm{SO}_{2} \text {, } \\
\text { organics }\end{array}$ & $\begin{array}{l}\text { Ship measurements of marine aerosol showed that } \\
\text { periods of high sub-micron CCN activity were } \\
\text { consistent with increased concentrations of MSA. } \\
\text { CCN and MSA/sulfate were strongly correlated. } \\
\text { Organics (primarily anthropogenic) are important } \\
\text { as acting as a site for sulfate condensation and } \\
\text { subsequent CCN activation. }\end{array}$ \\
\hline $\begin{array}{l}\text { Moore et al. } \\
\text { (2012) }\end{array}$ & $\begin{array}{l}\text { N.E. } \\
\text { Pacific }\end{array}$ & $\begin{array}{l}\text { AMS, SMPS, } \\
\text { CCN }\end{array}$ & Aircraft & $\begin{array}{l}\text { Dry } \\
\text { Aerosol }\end{array}$ & yes & yes & yes & yes & $\begin{array}{l}\text { organic, nitrate, } \\
\text { sulfate, } \\
\text { ammonium }\end{array}$ & $\begin{array}{l}\text { Detailed characterization of } \mathrm{CCN} \text { off the coast of } \\
\text { California are made and compared to CCN in urban } \\
\text { and rural areas. CCN-derived hygroscopicity } \\
\text { parameter was highest in marine outflow compared } \\
\text { to urban or rural areas. }\end{array}$ \\
\hline
\end{tabular}

PCASP - Passive Cavity Aerosol Sizing Probe; FSSP - Forward Scatter Spectrophotometer Probe; PSAP - Particle Soot Absorption Photometer; SMPS - Scanning Mobility Particle Sizer; PVM - Particle Volume Monitor; CCN - Cloud Condensation Nuclei; AMS - Aerosol Mass Spectrometer; LWC - Liquid Water Content; DASH-SP - Differential Aerosol Sizing and Hydroscopicity Spectrometer Probe; DNH - dual-nephelometer humidigraph; CVI - Counter-Flow Virtual Impactor; PILS-IC - Particle Into Liquid Sampler Ion Chromatography; MOUDI - Micro-Orifice Uniform-Deposit Impactor; AHS - Aerosol Hydration Spectrophotometer 
Table 2. Instruments onboard the Twin Otter aircraft and R/V Point Sur.

\begin{tabular}{|c|c|c|c|c|c|c|}
\hline Parameter & Instrument & Time Resolution & Detection Limit & Size Range & Twin Otter & Point Sur \\
\hline $\begin{array}{l}\text { Particle Number } \\
\text { Concentration }\end{array}$ & $\begin{array}{l}\text { Condensation Particle Counter } \\
\text { (TSI CPC 3010) }\end{array}$ & $1 \mathrm{~s}$ & $<50000 \mathrm{~cm}^{-3}$ & $\geq 10 \mathrm{~nm}$ & $\checkmark$ & $\checkmark$ \\
\hline Aerosol Size & Scanning Mobility Particle & $110 \mathrm{~s}$ & N/A & $10-700 \mathrm{~nm}$ & $\checkmark$ & $\checkmark$ \\
\hline Distribution & Sizer (SMPS) & & & & & \\
\hline Cloud Droplet & Counterflow Virtual & N/A & N/A & $>11 \mu \mathrm{m}$ & $\checkmark$ & \\
\hline Residuals & Impactor (CVI) & & & & & \\
\hline Bulk Cloud & Modified Mohen Slotted & N/A & N/A & N/A & $\checkmark$ & \\
\hline Water Composition & Cloud Water Collector & & & & & \\
\hline Cloud and Aerosol Size & Cloud and Aerosol Spectrometer & $1 \mathrm{~s}$ & N/A & $0.65-55 \mu \mathrm{m}$ & $\checkmark$ & \\
\hline Distribution & Probe (CAS) & & & & & \\
\hline Cloud Droplet Liquid & Light Diffraction & $1 \mathrm{~s}$ & N/A & $5-50 \mu \mathrm{m}$ & $\checkmark$ & \\
\hline Water Content & (Gerber PVM-100 probe) & & & & & \\
\hline Aerosol Bulk Composition & $\begin{array}{l}\text { High Resolution Time-of-Flight } \\
\text { Aerosol Mass Spectrometer (HiRes-ToF-AMS) }\end{array}$ & $2 \min$ & $\leq 1 \mu \mathrm{g} \mathrm{m}^{-3}$ & $60-600 \mathrm{~nm}$ & & $\checkmark$ \\
\hline Aerosol Bulk Composition & $\begin{array}{l}\text { Compact Time-of-Flight Aerosol } \\
\text { Mass Spectrometer (C-ToF-AMS) }\end{array}$ & $8-12 \mathrm{~s}$ & $\leq 1 \mu \mathrm{g} \mathrm{m} \mathrm{m}^{-3}$ & $60-600 \mathrm{~nm}$ & $\checkmark$ & \\
\hline $\begin{array}{l}\text { Cloud Condensation Nuclei } \\
\text { (CCN) Number Concentration }\end{array}$ & $\begin{array}{l}\text { Continuous Flow Streamwise Thermal } \\
\text { Gradient CCN chamber }\end{array}$ & $1-20 \mathrm{~s}$ & $<20000 \mathrm{~cm}^{-3}$ & s.s $0.2-0.7 \%$ & $\checkmark$ & $\checkmark$ \\
\hline
\end{tabular}

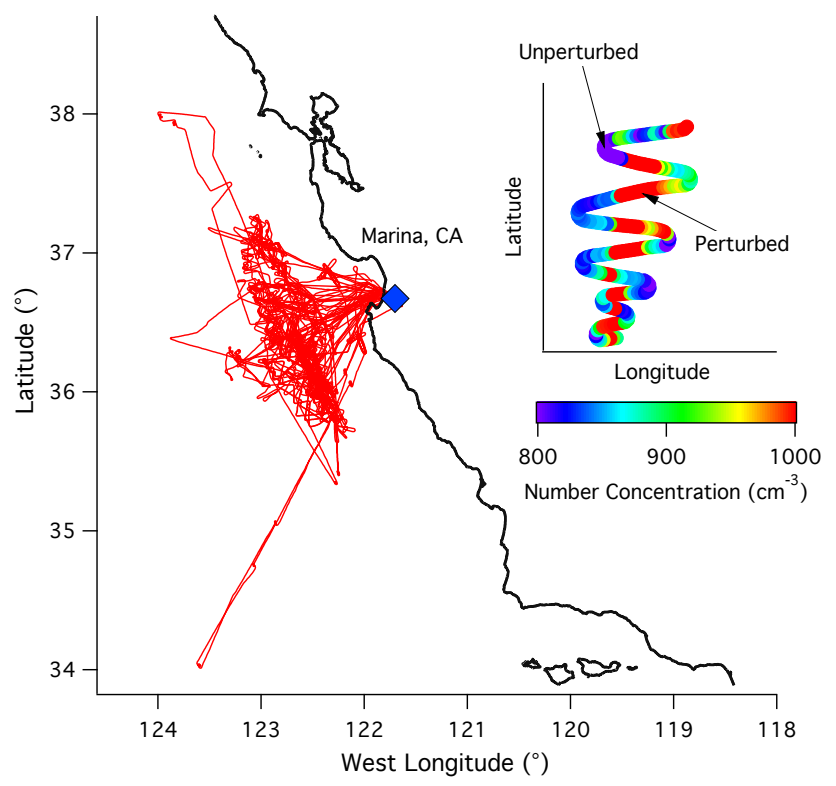

Fig. 1. Twin Otter flight paths for RF 1-26 during the E-PEACE mission. Inset shows a typical sampling pattern when encountering a ship exhaust plume. The color bar indicates the total aerosol number concentration as measured by the Twin Otter CPC.

decelerate airstream velocities outside the cabin $\left(\sim 50 \mathrm{~m} \mathrm{~s}^{-1}\right)$ to lower velocities that can be effectively sampled by aircraft instruments $\left(\sim 7 \mathrm{~m} \mathrm{~s}^{-1}\right)$. Under normal airspeed, the inlet on the Twin Otter samples aerosol below $3.5 \mu \mathrm{m}$ with $100 \%$ efficiency (Hegg et al., 2005). Thus, for the results reported here, there was no appreciable loss of particles due to aircraft sampling.

\section{Aerosol and cloud droplet properties}

In the following discussion, we use terminology such as "background" and "perturbed" to define aerosol conditions of the marine atmosphere. We acknowledge, however, that the assignment of these terms is not without ambiguity. A solely background signal in the remote marine atmosphere is a condition that occurs only when natural marine processes contribute to the aerosol. Without anthropogenic or continental influences, one might presume that a true baseline marine signal exists. However, even in a total absence of anthropogenic influence, such a signal is likely not unique and constant throughout the remote marine atmosphere. Varying wind speeds that generate sea spray, or biological production of dimethyl sulfide (DMS), which leads to homogeneously nucleated particles, can increase local "background" signal. On the other hand, varying wind speeds can dilute particles and lead to evaporation or ventilate DMS and inhibit new particle formation. Furthermore, particles can be lost due to wet or dry deposition. Even in the absence of non-marine sources, the natural background marine aerosol is dynamic.

Rather than relying on a definition of "background" aerosol, we choose to distinguish between "clean" and "perturbed" conditions based on the extent to which the marine atmosphere is impacted by shipping emissions. We define "perturbed" air masses as being pockets of the marine atmosphere that have been directly impacted by local ship emissions. This would comprise relatively small spatial regions in which the aerosol number concentration has increased, the aerosol number size distribution has shifted in mean diameter, and the aerosol composition has changed relative to the surrounding region. The atmosphere unperturbed by ship emissions, which we take to be synonymous with the term "clean", can be broken into a spectrum of conditions with varying degrees of non-ship related influences. Here, we are interested in comparing properties of the marine aerosol 
Table 3. Summary of average aerosol and cloud properties over the course of the E-PEACE campaign. Bottom table summarizes key aerosol properties from previous studies of marine aerosol and cloud droplets off the coast of Central California. Values in brackets represent standard deviations of the average. Values in parenthesis list the range of measurements. Values below detection limit (DL) are noted.

\begin{tabular}{|c|c|c|c|c|c|c|c|c|c|c|c|c|c|c|c|c|c|}
\hline \multirow[b]{2}{*}{$\begin{array}{l}\text { Research } \\
\text { Flight (RF) }\end{array}$} & \multirow[b]{2}{*}{ Date } & \multicolumn{6}{|c|}{ Below Cloud Aerosol Measurements } & \multicolumn{4}{|c|}{ Cloud Measurements $\mathrm{g}$} & \multicolumn{6}{|c|}{ Air Equivalent Cloud Water Chemistry } \\
\hline & & $\begin{array}{c}\text { Total } \\
\text { Mass }^{\mathrm{a}} \\
\left(\mu \mathrm{g} \mathrm{m}^{-3}\right)\end{array}$ & $\begin{array}{l}\text { Organic }^{\mathrm{a}} \\
\left(\mu \mathrm{g} \mathrm{m}^{-3}\right)\end{array}$ & $\begin{array}{l}\text { Sulfate }^{\mathrm{a}} \\
\left(\mu \mathrm{g} \mathrm{m}^{-3}\right)\end{array}$ & $\begin{array}{c}\mathrm{CPC} \\
\left(\mathrm{cm}^{-3}\right)\end{array}$ & $\begin{array}{c}\mathrm{CCN} \\
(0.15 \%) \\
\left(\mathrm{cm}^{-3}\right)\end{array}$ & $\begin{array}{l}\mathrm{CCN} \\
(0.3 \%) \\
\left(\mathrm{cm}^{-3}\right)\end{array}$ & $\begin{array}{c}\text { Total } \\
\text { Mass }^{\mathrm{a}} \\
\left(\mu \mathrm{g} \mathrm{m}^{-3}\right)\end{array}$ & $\begin{array}{l}\text { Organic }^{\mathrm{a}} \\
\left(\mu \mathrm{g} \mathrm{m}^{-3}\right)\end{array}$ & $\begin{array}{l}\text { Sulfate }^{\mathrm{a}} \\
\left(\mu \mathrm{g} \mathrm{m}^{-3}\right)\end{array}$ & $\begin{array}{c}N_{\mathrm{d}}^{\mathrm{b}} \\
\left(\mathrm{cm}^{-3}\right)\end{array}$ & $\mathrm{pH}$ & $\begin{array}{l}\mathrm{Na}\left(10^{4}\right) \\
\left(\mu \mathrm{g} \mathrm{m}^{-3}\right)\end{array}$ & $\begin{array}{l}\mathrm{Fe}\left(10^{4}\right) \\
\left(\mu \mathrm{g} \mathrm{m}^{-3}\right)\end{array}$ & $\begin{array}{l}\operatorname{Mn}\left(10^{4}\right) \\
\left(\mu \mathrm{g} \mathrm{m}^{-3}\right)\end{array}$ & $\begin{array}{l}\mathrm{V}\left(10^{4}\right) \\
\left(\mu \mathrm{gm}^{-3}\right)\end{array}$ & $\begin{array}{l}\mathrm{LWC}^{\mathrm{b}} \\
\left(\mathrm{gm}^{-3}\right)\end{array}$ \\
\hline 1 & $8 \mathrm{Jul}$ & 0.96 & 0.65 & 0.28 & 665 & - & 349 & 1.37 & 0.76 & 0.41 & 208 & 4.02 & 87182 & 51.41 & 4.72 & 0.59 & 0.10 \\
\hline 2 & $9 \mathrm{Jul}$ & 1.32 & 0.70 & 0.51 & 892 & - & 238 & 2.06 & 1.01 & 0.84 & 235 & 4.23 & 16956 & 26.63 & 2.12 & 2.12 & 0.09 \\
\hline 4 & $14 \mathrm{Jul}$ & 1.04 & 0.60 & 0.45 & 968 & - & 131 & 1.68 & 0.84 & 0.69 & 93 & 4.32 & 7757 & $<(\mathrm{DL})$ & $<(\mathrm{DL})$ & 1.29 & 0.15 \\
\hline 5 & $15 \mathrm{Jul}$ & 0.86 & 0.75 & 0.20 & 364 & - & 78 & 0.92 & 0.49 & 0.20 & 23 & 4.63 & 688 & 0.19 & 0.07 & 0.31 & 0.01 \\
\hline 6 & $16 \mathrm{Jul}$ & 0.90 & 0.58 & 0.31 & 329 & - & - & 1.06 & 0.67 & 0.22 & 27 & 4.50 & 127 & $<(\mathrm{DL})$ & $<(\mathrm{DL})$ & 2.02 & 0.11 \\
\hline $7^{\mathrm{c}}$ & $17 \mathrm{Jul}$ & 0.77 & 0.72 & 0.18 & 341 & - & - & - & - & - & - & - & - & - & - & - & - \\
\hline 8 & $19 \mathrm{Jul}$ & 0.88 & 0.44 & 0.40 & 323 & - & - & 1.24 & 0.68 & 0.54 & 145 & 4.21 & 3671 & 11.78 & 0.52 & 4.25 & 0.19 \\
\hline 9 & $21 \mathrm{Jul}$ & 1.83 & 0.70 & 0.78 & 578 & 217 & - & 1.08 & 0.63 & 0.39 & 127 & 5.16 & 17662 & 4.85 & 3.11 & 1.50 & 0.23 \\
\hline 10 & $22 \mathrm{Jul}$ & 1.80 & 0.49 & 1.02 & 376 & 213 & - & 1.81 & 0.79 & 0.78 & 116 & 4.67 & 15212 & 7.58 & 1.08 & 2.46 & 0.25 \\
\hline 11 & $23 \mathrm{Jul}$ & 2.83 & 0.86 & 1.56 & 976 & 300 & 400 & 1.84 & 0.88 & 0.81 & 169 & 4.30 & 13881 & 17.61 & 1.55 & 3.28 & 0.18 \\
\hline 12 & $24 \mathrm{Jul}$ & 2.81 & 0.92 & 1.57 & 736 & 226 & 355 & 1.90 & 0.87 & 0.85 & 170 & 3.99 & 5362 & 15.95 & 1.36 & 3.12 & 0.10 \\
\hline 13 & $26 \mathrm{Jul}$ & 0.99 & 0.60 & 0.34 & 221 & 75 & 116 & 1.04 & 0.56 & 0.32 & 87 & 4.95 & 11702 & 5.13 & 0.41 & 4.11 & 0.23 \\
\hline $14^{\mathrm{d}}$ & $27 \mathrm{Jul}$ & 2.99 & 0.81 & 1.91 & 425 & 207 & - & 1.53 & 0.64 & 0.80 & 199 & 3.86 & 4587 & 34.05 & 2.29 & 16.78 & 0.22 \\
\hline 15 & $28 \mathrm{Jul}$ & 4.74 & 1.06 & 3.14 & 589 & 101 & 406 & 4.98 & 2.21 & 2.50 & 327 & 2.92 & 10772 & 86.28 & 4.89 & 43.08 & 0.12 \\
\hline 16 & $29 \mathrm{Jul}$ & 2.62 & 0.70 & 1.59 & 465 & 96 & 304 & 2.14 & 0.89 & 1.13 & 252 & 3.84 & 3664 & 164.63 & 17.47 & 19.99 & 0.28 \\
\hline 17 & 1 Aug & 2.22 & 0.58 & 1.44 & 400 & 78 & 352 & 1.86 & 0.62 & 1.10 & 212 & 3.77 & 978 & 47.07 & 2.71 & 7.35 & 0.10 \\
\hline 18 & 2 Aug & 2.55 & 0.80 & 1.47 & 587 & 184 & 335 & 2.34 & 1.00 & 1.13 & 269 & 4.07 & 2777 & 27.67 & 1.98 & 8.92 & 0.21 \\
\hline 19 & 3 Aug & 1.41 & 0.57 & 0.70 & 346 & 167 & 173 & 1.11 & 0.60 & 0.38 & 120 & 4.80 & 11406 & $<(\mathrm{DL})$ & 0.45 & 3.63 & 0.19 \\
\hline $20^{c}$ & 4 Aug & 1.08 & 0.52 & 0.55 & 229 & 44 & 83 & - & - & - & - & - & - & - & - & - & - \\
\hline 21 & 5 Aug & 2.06 & 0.65 & 1.17 & 561 & 63 & 254 & 1.13 & 0.57 & 0.48 & 163 & 4.65 & 8376 & 19.06 & 1.69 & 1.03 & 0.19 \\
\hline 22 & 8 Aug & 3.75 & 1.01 & 2.24 & 737 & 328 & 333 & 2.03 & 0.52 & 1.30 & 323 & 3.66 & 42794 & 26.45 & 1.31 & 4.17 & 0.11 \\
\hline 23 & 9 Aug & 2.97 & 0.92 & 1.73 & 428 & 28 & 294 & 1.79 & 0.75 & 0.80 & 226 & 4.06 & 34543 & 13.77 & 1.01 & 1.24 & 0.11 \\
\hline 24 & 10 Aug & 1.57 & 0.83 & 0.79 & 296 & 49 & 296 & 0.99 & 0.65 & 0.41 & 150 & 4.54 & 27015 & 31.42 & 1.76 & 7.64 & 0.25 \\
\hline 25 & $11 \mathrm{Aug}$ & 1.18 & 0.53 & 0.46 & 252 & 157 & 91 & 0.86 & 0.58 & 0.21 & 41 & 5.07 & 1538 & 1.86 & 0.59 & 3.97 & 0.13 \\
\hline \multirow[t]{4}{*}{26} & 12 Aug & 3.49 & 1.24 & 1.94 & 670 & - & 459 & 1.80 & 0.71 & 0.97 & 257 & 3.90 & 32109 & 17.24 & 1.07 & 3.56 & 0.14 \\
\hline & Min & 0.77 & 0.44 & 0.18 & 221 & 28 & 78 & 0.86 & 0.49 & 0.20 & 23 & 2.92 & 127 & 0.19 & 0.07 & 0.31 & 0.01 \\
\hline & Max & 4.74 & 1.24 & 3.14 & 976 & 328 & 459 & 4.98 & 2.21 & 2.50 & 327 & 5.16 & 87182 & 164.63 & 17.47 & 43.08 & 0.28 \\
\hline & & \multicolumn{6}{|c|}{ Below Cloud Aerosol Measurements } & \multicolumn{4}{|c|}{ Cloud Measurements ${ }^{\mathrm{g}}$} & \multicolumn{6}{|c|}{ Air Equivalent Cloud Water Chemistry } \\
\hline $\begin{array}{l}\text { Author/ } \\
\text { Mission }\end{array}$ & Date & $\begin{array}{c}\text { Total } \\
\text { Mass }^{\mathrm{a}} \\
\left(\mu \mathrm{g} \mathrm{m}^{-3}\right)\end{array}$ & $\begin{array}{l}\text { Organic }^{\mathrm{a}} \\
\left(\mu \mathrm{g} \mathrm{m}^{-3}\right)\end{array}$ & $\begin{array}{l}\text { Sulfate }^{\mathrm{a}} \\
\left(\mu \mathrm{g} \mathrm{m}^{-3}\right)\end{array}$ & $\begin{array}{c}\mathrm{CPC} \\
\left(\mathrm{cm}^{-3}\right)\end{array}$ & $\begin{array}{c}\mathrm{CCN} \\
(0.15 \%) \\
\left(\mathrm{cm}^{-3}\right) \\
\end{array}$ & $\begin{array}{l}\mathrm{CCN} \\
(0.3 \%) \\
\left(\mathrm{cm}^{-3}\right)\end{array}$ & $\begin{array}{r}\text { Total } \\
\text { Mass } \\
\left(\mu \mathrm{g} \mathrm{m}^{-3}\right)\end{array}$ & $\begin{array}{l}\text { Organic }^{\mathrm{a}} \\
\left(\mu \mathrm{g} \mathrm{m}^{-3}\right)\end{array}$ & $\begin{array}{l}\text { Sulfate }^{\mathrm{a}} \\
\left(\mu \mathrm{g} \mathrm{m}^{-3}\right)\end{array}$ & $\begin{array}{c}N_{\mathrm{d}}^{\mathrm{b}} \\
\left(\mathrm{cm}^{-3}\right)\end{array}$ & $\mathrm{pH}$ & $\begin{array}{l}\mathrm{Na}\left(10^{4}\right) \\
\left(\mu \mathrm{g} \mathrm{m}^{-3}\right)\end{array}$ & $\begin{array}{l}\mathrm{Fe}\left(10^{4}\right) \\
\left(\mu \mathrm{g} \mathrm{m}^{-3}\right)\end{array}$ & $\begin{array}{l}\operatorname{Mn}\left(10^{4}\right) \\
\left(\mu \mathrm{g} \mathrm{m}^{-3}\right)\end{array}$ & $\begin{array}{l}\mathrm{V}\left(10^{4}\right) \\
\left(\mu \mathrm{g} \mathrm{m}^{-3}\right)\end{array}$ & $\begin{array}{l}\mathrm{LWC}^{\mathrm{b}} \\
\left(\mathrm{g} \mathrm{m}^{-3}\right)\end{array}$ \\
\hline E-PEACE & Jul-Aug & 1.98 & 0.73 & 1.07 & 510 & 148 & 266 & 1.67 & 0.78 & 0.75 & 171 & 4.48 & 13227 & 23 & 2.3 & 5.4 & 0.16 \\
\hline Average & 2011 & {$[1.07]$} & {$[0.19]$} & {$[0.76]$} & [225] & [91] & {$[120]$} & {$[0.85]$} & {$[0.34]$} & {$[0.50]$} & [86] & {$[0.72]$} & [15 531] & [37] & [4.1] & [7] & {$[0.07]$} \\
\hline \multicolumn{18}{|c|}{ Hegg et al. $(2010)^{\mathrm{e}}$} \\
\hline CARMA II & Jul 2004 & 3.12 & - & 1.34 & - & - & $100-825$ & - & - & - & - & - & - & - & - & - & - \\
\hline CARMA III & Aug 2005 & 3.93 & - & 1.3 & - & - & $75-1150$ & - & - & - & - & - & - & - & - & - & - \\
\hline CARMA IV & Aug 2007 & 16.3 & - & 1.04 & $197-6104$ & - & $50-700$ & - & - & - & - & - & - & - & - & - & - \\
\hline $\begin{array}{l}\text { Sorooshian et al. } \\
\text { (2009) }\end{array}$ & Jul 2007 & - & - & $\begin{array}{c}0.78 \\
{[0.59]}\end{array}$ & $\begin{array}{c}307 \\
{[239]}\end{array}$ & - & $\begin{array}{c}73 \\
{[27]}\end{array}$ & $\begin{array}{l}- \\
-\end{array}$ & - & - & $\begin{array}{l}104 \\
{[56]}\end{array}$ & - & - & - & - & - & $\begin{array}{c}0.15 \\
{[0.07]}\end{array}$ \\
\hline $\begin{array}{l}\text { MASE II } \\
\text { McInnes et al. } \\
(1996)^{\mathrm{f}}\end{array}$ & $\begin{array}{c}\text { Apr-Jun } \\
1994\end{array}$ & $\begin{array}{c}2.21 \\
{[1.16]}\end{array}$ & - & - & - & - & - & - & - & - & - & - & - & - & - & - & - \\
\hline $\begin{array}{l}\text { Straub et al. } \\
\text { (2007) } \\
\text { DYCOMS-II }\end{array}$ & Jul 2001 & - & - & - & - & - & - & - & - & - & $\begin{array}{l}174 \\
{[79]}\end{array}$ & $3.26-4.82$ & $\begin{array}{c}38900 \\
(3900- \\
133900)\end{array}$ & $\begin{array}{c}71 \\
(0-369)\end{array}$ & $\begin{array}{c}2.3 \\
(0-11.6)\end{array}$ & - & $\begin{array}{c}0.33 \\
{[0.17]}\end{array}$ \\
\hline
\end{tabular}

a Measurements from AMS.

$\mathrm{b}$ Averaged cloud probe data during cloud water sampling period.

c No clouds (7/17), few cloud measurements by probes (8/4).

d AMS Failure - limited measurements available below cloud (7/27).

e Filter samples for aerosol $>0.2 \mu \mathrm{m}$ in diameter.

${ }^{\mathrm{f}}$ Filter samples for aerosol $<1 \mu \mathrm{m}$ in diameter.

g Organics, sulfate and total mass concentrations measured behind the CVI are a fraction of the total loading and may not reflect absolute mass concentrations. See text for details.

during periods of high aerosol mass loading owing to ship emissions (defined here as "perturbed") with properties in adjacent air masses not directly impacted by ship emissions (defined here as "clean"). The nature of non-refractory marine aerosol (i.e., non sea salt components such as organics and sulfate) can be consistently categorized using data from the aerosol mass spectrometer (AMS), which transmits particles with vacuum diameters ranging between $60-600 \mathrm{~nm}$ with $100 \%$ transmission efficiency. Initially we will rely on bulk AMS mass concentrations as the basis on which to identify and define "clean" and "perturbed" conditions, but subsequently, we will derive conditions that more concretely define air masses directly impacted by shipping emissions.

Table 3 reports average aerosol properties for each flight compared to measurements reported by other studies con- ducted in the Eastern Pacific. We note that observations from this study agree broadly with previous findings. Notably, aerosol mass measured by the AMS agrees well with that measured by filter sampling reported in McInnes et al. (1996). Mass loadings from this study reflect submicrometer, non-refractory aerosol, whereas loadings reported by McInnes et al. (1996) reflect total submicrometer mass. The close agreement suggests that the mass measured in the submicrometer regime is dominated by non-sea salt components. This is consistent with McInnes et al. (1997) who show that $87-96 \%$ of the total number concentration of submicrometer particles in the remote marine atmosphere are non-sea salt.

We can use the results from Table 3 to identify flights that were clean and perturbed during the E-PEACE campaign. Figure 2 shows the mass contributions of bulk AMS 
species to dry marine aerosol and cloud droplet residuals over the course of the study. As is also shown in Table 3, submicrometer aerosol mass concentrations strongly varied between flights. In the beginning of the study, a continual period of low aerosol loading was observed between 15-19 July (RF 5-8). These measurements yielded aerosol mass concentrations below $1 \mu \mathrm{g} \mathrm{m}^{-3}$ and were among the lowest aerosol concentrations observed during E-PEACE. In the present study, these were likely to have been the least influenced by shipping emissions and are therefore defined as "clean".

Clean conditions have been previously observed in the marine atmosphere and are known to vary greatly (e.g., McInnes et al., 1996; Phinney et al., 2006; Straub et al., 2007; Langley et al., 2010; Ovadnevaite et al., 2011). For example, using an AMS, Phinney et al. (2006) measured submicrometer aerosol mass concentrations of $1.4 \mu \mathrm{g} \mathrm{m}^{-3}$ in the remote sub-arctic Pacific Ocean. The majority of the mass was sulfate $\left(0.74 \mu \mathrm{g} \mathrm{m}^{-3}\right)$, of which MSA was found to contribute significantly, however organics were also a large fraction of the total signal $\left(0.3 \mu \mathrm{g} \mathrm{m}^{-3}\right)$. Ammonium and nitrate were present in low amounts, which is consistent with the results from this study (see Fig. 2). In contrast, Ovadnevaite et al. (2011) observed organic aerosol mass concentrations as high as $3.8 \mu \mathrm{g} \mathrm{m}^{-3}$ during high wind events from clean marine air masses. The organic mass spectra and the observation of high biological activity suggested a primary organic source. In Sect. 3.5, we show that the origin of air masses sampled during RF 5-8 was remote marine. Of the previous studies that we have discussed, the clean conditions in this study are most consistent with measurements by Phinney et al. (2006) and McInnes et al. (1996). However, as has been shown, for example, by authors like Ovadnevaite et al. (2011), clean marine environments can exhibit a large range of aerosol mass concentrations.

Of particular interest in the present study are flights with elevated sulfate concentrations. Sulfate in the marine atmosphere is primarily attributed to DMS, continental pollution, and shipping exhaust. Flights conducted between 27 July-2 August (RF 14-18) exhibited enhancements in total aerosol mass concentrations that were nearly double the amount observed during clean conditions. These flights also had some of the highest concentrations of sulfate below cloud and in residual cloud droplets. Though there were other flights in which the total aerosol mass concentration was high, the period during RF 14-18 represents nearly a week of uninterrupted enhancements in aerosol mass. Thus, we focus our attention to these flights and define them as "perturbed".

\subsection{Cloud-processed aerosol}

Figure 3 shows typical marine aerosol number size distributions as measured by the scanning mobility particle sizer (SMPS). In general, marine aerosol exhibits two modes at approximately 60 and $200 \mathrm{~nm}$, respectively. The peak at

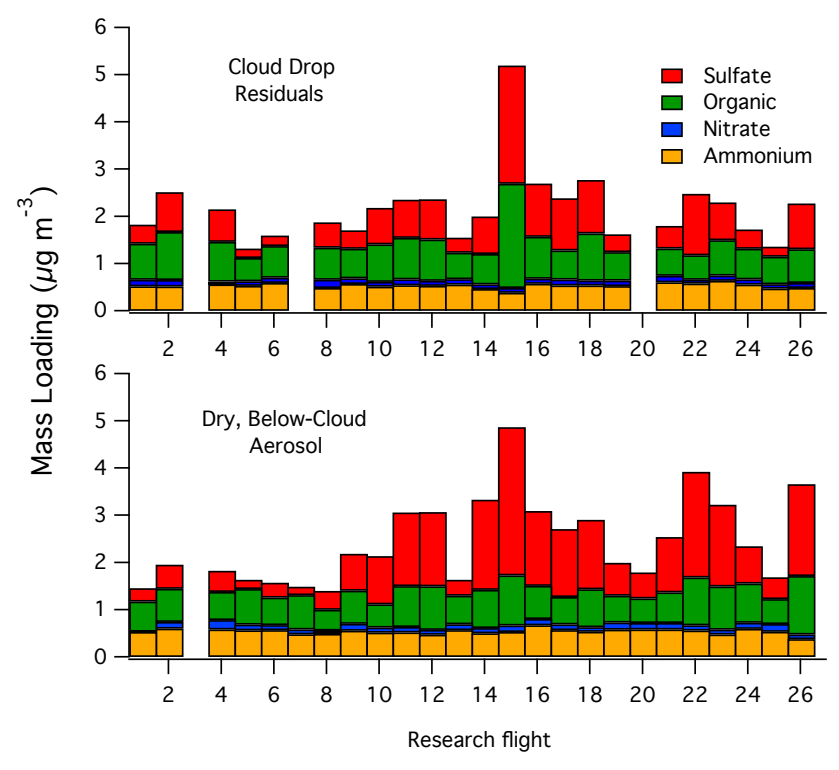

Fig. 2. Bulk AMS species measured in cloud drop residuals (top panel) and dry, below-cloud aerosol (bottom panel) over the course of the study. Only organic and sulfate vary significantly each day (variance of organic $=0.04$, sulfate $=0.6$ in below-cloud aerosol) . Ammonium and nitrate exhibit variances that are at most $0.5 \%$ of the variance of sulfate.

$200 \mathrm{~nm}$, which is the accumulation mode commonly observed in regions with marine stratocumulus (Hoppel et al., 1986, 1994; Frick and Hoppel, 2000), may be indicative of cloud processing. We note, however, that other sources can contribute to this mode. For example, Phinney et al. (2006) observed organic mass distributions during periods of direct ship fumigation with modes between $150-200 \mathrm{~nm}$ which may enhance number concentrations in this "cloudprocessed" mode. However, given that most flights were conducted in the presence of marine stratocumulus, we suspect that cloud processing was a major contributor to aerosol in the accumulation mode.

During perturbed flights, the total aerosol volume concentration is approximately twice as large as that for clean flights. For example, the aerosol volume concentration for flights 16, 26 (perturbed) and 8, 20 (clean) are 2.24, $2.74 \mu \mathrm{m}^{3} \mathrm{~cm}^{-3}$ and $1.47,0.47 \mu \mathrm{m}^{3} \mathrm{~cm}^{-3}$, respectively. Representative size distributions of fresh ship exhaust from three ships (Fig. 3, bottom panel) exhibit a primary mode between 56-73 nm, which falls in the range of non cloud-processed aerosol. It is possible that ship emissions enhanced the number concentration of small mode aerosol during perturbed flights.

Cloud processing likely affected aerosol composition (Fig. 4), which is consistent with previous studies. Cloud scavenging and subsequent reaction of gaseous sulfur species lead to the accumulation of sulfate (Faloona (2009) and references therein). Under conditions of low acidity, some 


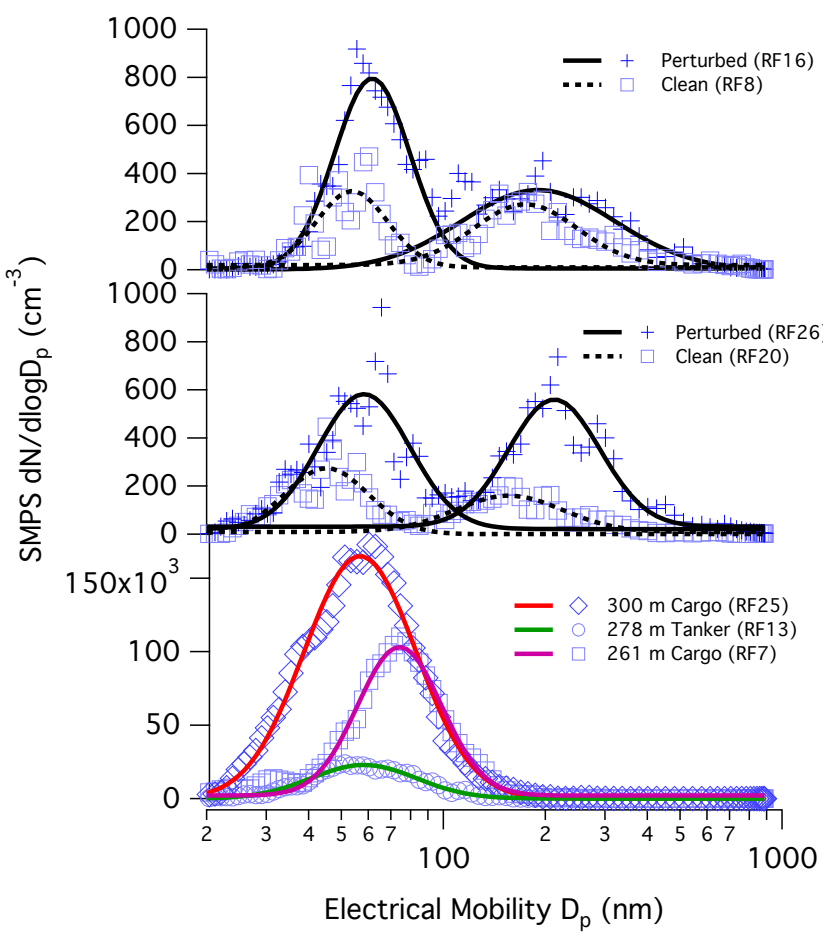

Fig. 3. Marine aerosol number size distributions of below-cloud aerosol measured during clean and perturbed flights (top and middle panels). Aerosol size distributions for the exhaust of three ships (bottom panel). Lines are log-normal fits.

studies have shown that organics can also be formed from aqueous-phase processing. If the $\mathrm{pH}$ is high enough, the uptake and reaction of organic precursors (e.g., glyoxal and acetic acid) may exceed that of $\mathrm{SO}_{2}$ (Ervens et al., 2003a,b; Sorooshian et al., 2007a) For example, Sorooshian et al. (2007a,b), showed that the ratio of oxalate:sulfate increases in cloud droplets with higher liquid water content (LWC). After the droplet evaporates, low volatility organics that may be formed by aqueous-phase chemistry remain in particle residuals (Sorooshian et al. (2007a) and references therein). Figure 4 shows the average out-of-cloud organic:sulfate ratio as a function of altitude. As observed by Sorooshian et al. (2007a), the ratio of organic:sulfate increases with altitude, a finding that is also coincident with an average increase in LWC. Though we suspect that this may be an indication of aqueous-phase chemistry, there are other processes that could affect the organic : sulfate ratio. During a typical flight, aerosol above cloud top exhibited high concentrations of organic. Previous studies have found that entrainment of air from the free troposphere into the marine boundary layer is a major source of aerosol number (Katoshevski et al., 1999; Kazil et al., 2011). If this aerosol were to be entrained into the cloud, this would elevate organic : sulfate ratios. Furthermore, it is possible that the dry aerosol shown in Fig. 4 did not result from evaporated cloud particles; rather, the aerosol could be the result of incomplete particle activation. Inor-

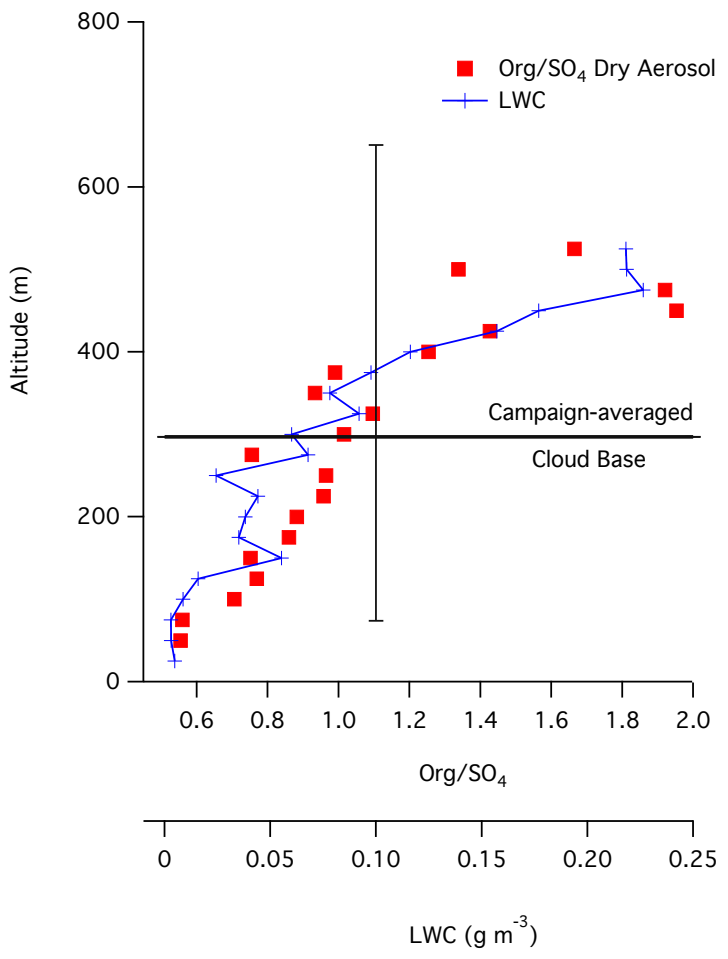

Fig. 4. Average organic:sulfate mass ratio of dry, unperturbed marine aerosol sampled in cloud-free air as a function of altitude. For clarity, standard deviations bars are omitted, however we note that variation increased with altitude. Average LWC is presented to illustrate the study-averaged, below-cloud top liquid water profile and show that cloud processing was prevalent at all altitudes. The campaign-average cloud base is shown with bars depicting the range of cloud bases and tops observed during the campaign. Cloud base altitudes were measured during aircraft soundings.

ganic salts often increase the activation of organic aerosol particles (e.g. Bilde and Svenningsson, 2004). Thus, particles with higher amounts of sulfate may activate to cloud droplets first, therefore leaving behind interstitial aerosol with higher concentrations of organic. Despite these effects, it appears that cloud processing may have played a significant role controlling aerosol composition in the present study, which is consistent with the observation of a cloud-processed mode in the aerosol size distribution data (Fig. 3).

\subsection{Cloud water chemistry}

Figure 5 summarizes the trends in major cloud water ion and metal concentrations. These data are presented similarly to those reported by Straub et al. (2007) and Benedict et al. (2012), such that the present values can be easily compared. In this study, $\mathrm{Cl}^{-}, \mathrm{SO}_{4}^{2-}$, and $\mathrm{NO}_{3}^{-}$are measured by $\mathrm{IC}$ and are therefore representative of soluble ions. Species such as $\mathrm{Na}, \mathrm{Ca}, \mathrm{Mg}$ and $\mathrm{K}$ are measured by ICP-MS. This analysis technique strictly gives information about the total metal content. In order to compare the results of the present study 

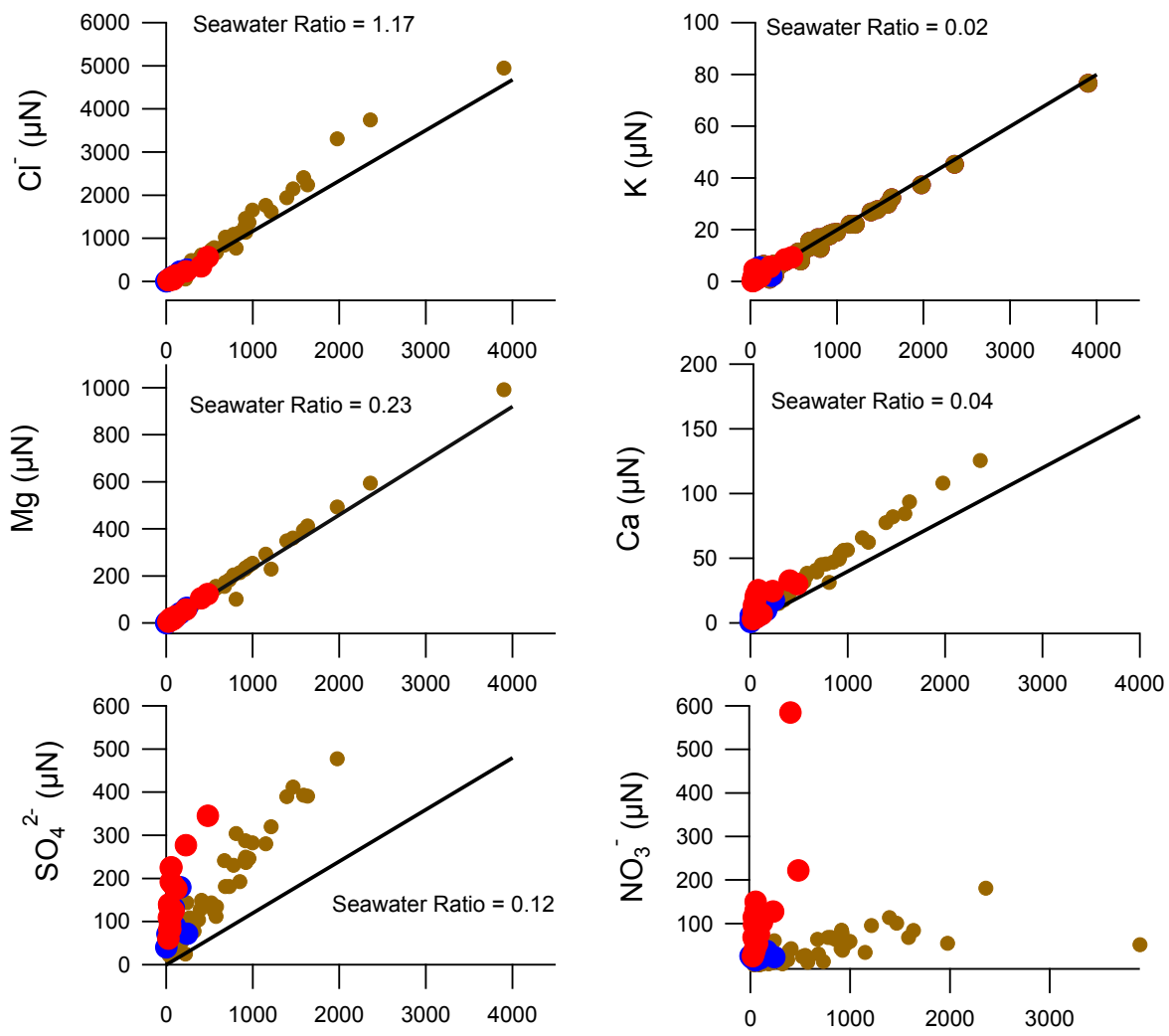

- Clean

- Perturbed

\section{Cloud Water $\mathrm{Na}(\mu \mathrm{N})$}

Fig. 5. Summary of major seawater species measured in marine cloud water. Data are presented analogously to those reported by Straub et al. (2007) and Benedict et al. (2012). In the present study, we assume that seawater species measured by ICP-MS (e.g., Na, K, Mg, Ca) reflect aqueous phase ions. The solid lines indicate the ion ratio typically observed in seawater. Each point represents a single cloud water measurement. Clean flights (RF 5-8) are colored in blue while perturbed flights (RF 14-18) are colored in red. The remainder of the flights are shown as brown circles.

to those by Straub et al. (2007) and Benedict et al. (2012), we assume that those species measured by ICP-MS originate from soluble seawater species and represent the ion content of each sample. Furthermore, to calculate concentrations in units of normality $(\mu \mathrm{N})$, we assume that when present in the aqueous phase, these metals exist in their most stable valence state (for example, we assume that magnesium measured by ICP-MS exists as $\mathrm{Mg}^{2+}$ ). If we assume that sodium concentrations reported in this study are representative of soluble sodium with +1 valence, then E-PEACE concentrations $(0.7-3900 \mu \mathrm{N})$ are consistent with those observed by Straub et al. (2007) $(36-2784 \mu \mathrm{N})$. Of all the common seawater species, $\mathrm{Cl}^{-}, \mathrm{Mg}$, and $\mathrm{K}$ exhibit a ratio with respect to $\mathrm{Na}$ that is consistent with the global average ratio found in seawater. Calcium is observed at a ratio slightly higher than typical seawater. Similar enhancements in calcium have been observed previously (e.g., Straub et al., 2007; Benedict et al., 2012) and may be the result of dissolved crustal minerals. The strong linear correlation with sodium, however, implies that the variation in calcium was primarily influenced by sea spray.

Of particular interest is the variation of seawater species between flights. Markers in Fig. 5 colored by blue and red indicate flights performed during clean (RF 5-8) and perturbed (RF 14-18) conditions, respectively. In general, the concentration of seawater species in marine cloud water is invariant during clean and perturbed flights. These species also appear to be present at lower concentrations during these flights than compared to all other flights performed during E-PEACE. It is reasonable, therefore, to neglect the mass contribution from seawater to the variation of sulfate observed in Table 3 and Fig. 2, given that clean and perturbed flights show little variation in sea-related species.

Sulfate and nitrate in the present study do not exhibit a strong linear relationship with sodium. These species are also enhanced during perturbed conditions (Fig. 5). In Sect. 3.4, we show that metals associated with shipping emissions (such as vanadium) are also enhanced during perturbed conditions and that their variation is coincident with higher 
concentrations of sulfate in dry marine aerosol. It is possible that enhanced sulfate and nitrate in cloud water samples originated from ship-impacted air masses.

\subsection{CCN measurements}

Marine aerosol $\mathrm{CCN}$ measurements are summarized in Fig. 6. In the top panel, $\mathrm{CCN}$ activation spectra are compared for perturbed (red, RF 15) and clean (blue, RF 20) flights. In general, the fraction of activated particles at a given supersaturation is enhanced under perturbed conditions. For example, at $0.7 \%$ supersaturation, $90 \%$ of the particles measured during RF 15 activate in the $\mathrm{CCN}$ instrument. In contrast, only $60 \%$ of the particles activate in the instrument during RF 20. If we fit a sigmoidal curve of the form $\mathrm{CCN} / \mathrm{CN}=a_{0} /\left(1+\left(x / a_{1}\right)^{-a_{2}}\right)$ (where $a_{0}, a_{1}$ and $a_{2}$ are fitted parameters) and take the inflection point to reflect the aerosol population ensemble critical supersaturation (Moore et al., 2011), we find that the critical supersaturation is lower for particles measured during RF 15 than those measured during RF $20(0.23 \%$ vs. $0.27 \%)$. While this does not represent a significant difference in supersaturation, it appears that higher fractions of particles activate to $\mathrm{CCN}$ under perturbed conditions relative to clean conditions.

The bottom panel in Fig. 6 shows the fraction of activated particles at $0.15,0.3,0.5$ and $0.7 \%$ supersaturation for all dry aerosol measurements. Markers are colored by sulfate loading to illustrate the extent to which shipping emissions may have influenced the measurement. In general, a higher fraction of activated particles is coincident with elevated concentrations of sulfate. This is consistent with the averaged spectrum in Fig. 6 (top) which shows that more particles activated during perturbed flight RF 15 compared to clean flight RF 20. From Fig. 3, we see that the aerosol measured during RF 20 exhibited two modes that, when normalized by total aerosol number, have similar peak shape to aerosol measured during a perturbed flight (e.g., RF 16). The only observable difference in normalized number size distributions is that the small mode from RF 20 peaks at a smaller diameter $(40 \mathrm{~nm})$ than RF $16(60 \mathrm{~nm})$. While this may partially explain the increased fraction of $\mathrm{CCN}$ during perturbed conditions, the enhancement of activated particles may also result from elevated concentrations of sulfate (as shown in Fig. 6).

Enhanced CCN concentrations in the presence of anthropogenic pollution events has been previously observed in the Eastern Pacific (Hegg et al., 2009, 2010; Langley et al., 2010). Langley et al. (2010) found that anthropogenic pollution acted as condensation sites for sulfur species, resulting in an increase in $\mathrm{CCN}$ number concentrations. Hegg et al. (2010) deduced that $67 \%$ of the CCN off the coast of California are anthropogenic in origin. The CCN concentrations reported in the present study are consistent with those results (see Table 3 comparison), suggesting that anthropogenic sources are major contributors to the CCN properties reported in Fig. 6. In Sect. 3.4, we show that increased

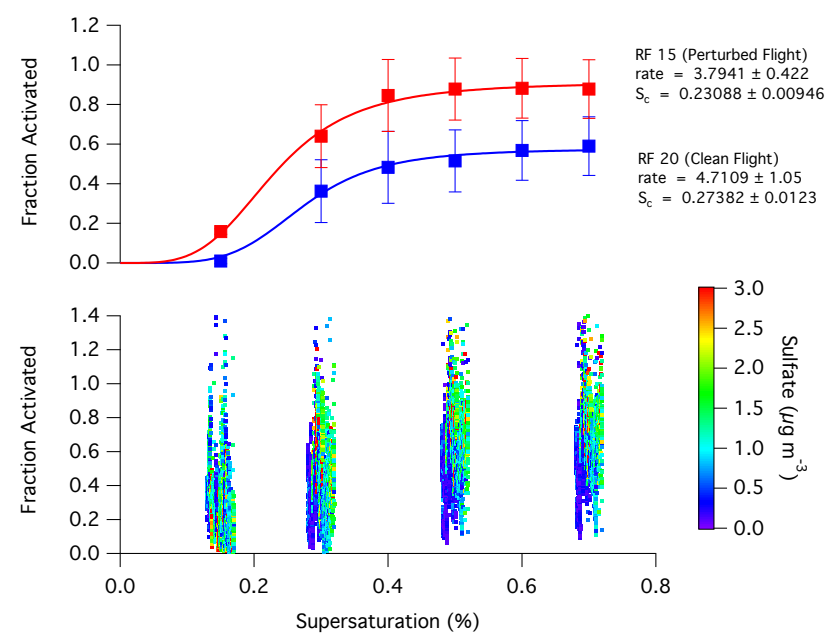

Fig. 6. CCN spectra showing the activation of particles at various supersaturations. The top panel is $\mathrm{CCN}$ data from a perturbed flight (red markers, RF 15) and clean flight (blue markers, RF 20) fitted to a sigmoidal curve of the form $\mathrm{CCN} / \mathrm{CN}=a_{0} /\left(1+\left(x / a_{1}\right)^{-a_{2}}\right)$ where $a_{0}, a_{1}$ and $a_{2}$ are fitted parameters. The error bars represent the measurement standard deviation. The bottom panel shows all $\mathrm{CCN}$ measurements made over the course of the campaign at $0.15,0.3$, 0.5 and $0.7 \%$ supersaturation.

sulfate can be primarily linked to shipping emissions; thus, shipping emissions may have exerted a strong control on $\mathrm{CCN}$ properties during this study.

\subsection{Relationship between marine aerosol and cloud droplet properties}

In this study, sulfate is a major constituent of submicrometer marine aerosol (Fig. 2). Sulfate affects cloud water chemistry and cloud droplet number concentrations by lowering cloud water $\mathrm{pH}$ (via $\mathrm{SO}_{2}$ oxidation) and increasing $\mathrm{CCN}$ concentrations (e.g., ship emissions, homogeneous nucleation of $\mathrm{H}_{2} \mathrm{SO}_{4}$ or MSA) (Hegg and Hobbs, 1986; Hoppel et al., 1994; Straub et al., 2007; Hegg et al., 2010; Langley et al., 2010). Sources of sulfate in the marine atmosphere include ship emissions, DMS, and continental pollution. Here, we relate sulfate measured below cloud to properties of cloud water chemistry and present evidence that elevated sulfate measured during perturbed flights was largely influenced by ship emissions. In the present discussion, we only compare trace metals such as iron and vanadium due to their links to shipping. Subsequent work will provide a more complete overview of cloud water chemistry during the E-PEACE campaign.

Figure 7 compares below-cloud sulfate with various cloud properties. Iron and vanadium were measured in cloud water samples using ICP-MS, while hydronium concentrations were calculated from cloud water $\mathrm{pH}$. All data are presented in air equivalent units, which represents the mass of a species per unit volume of air (see Appendix A for details). We 


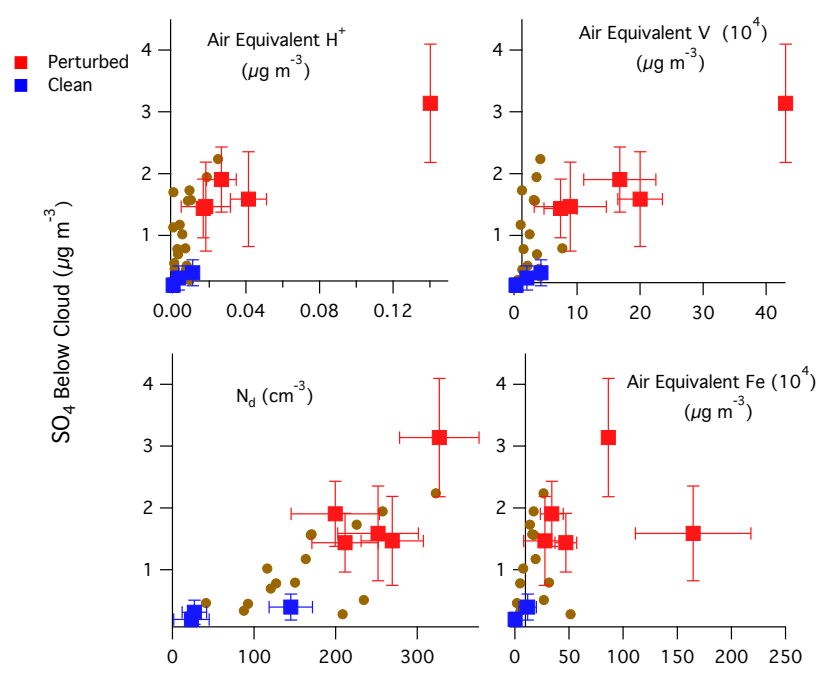

Fig. 7. Trends in below cloud sulfate vs. air equivalent $\mathrm{H}^{+}$, cloud droplet number concentration $\left(N_{\mathrm{d}}\right)$, air equivalent $\mathrm{V}$ and air equivalent $\mathrm{Fe}$. Iron and vanadium were measured in cloud water samples using ICP-MS. Hydronium concentrations were calculated based on cloud water sample $\mathrm{pH}$. Air equivalent units are calculated as the product of the concentration of a species in a bulk cloud water sample and the average liquid water content measured during the cloud water collection period. Each point represents a single flight. Clean flights (RF 5-8) are colored blue while perturbed flights (RF 14-18) are colored red. Error bars show the standard deviation of each measurement. The remainder of the flights are shown as brown circles.

observe that sulfate in below-cloud aerosol correlates well with $\mathrm{pH}$ (not shown) and cloud droplet number concentration ( $R^{2}=-0.57$ and 0.64 , respectively). This is consistent with observations of enhanced cloud water acidification and CCN in the presence of sulfate (e.g., Hoppel et al., 1994; Straub et al., 2007; Langley et al., 2010). Perturbed flights exhibit greater acidification in cloud water samples and higher concentrations of cloud droplets, vanadium, and iron as compared to clean flights. Of all the flights, the highest concentration of sulfate below cloud occurred during RF 15, which also exhibited the greatest amount of acidification, highest concentration of vanadium, highest concentration of cloud droplets, and second highest concentration of iron in cloud water samples. This enhancement is clearly seen in Table 3, where perturbed flights 14-18 exhibit 5-10 times higher concentrations of iron and vanadium than clean flights.

The hypothesis in the present study is that cloud water acidification results from the oxidation of $\mathrm{SO}_{2}$ originating from ship emissions. This could occur by several mechanisms. $\mathrm{SO}_{2}$ could be oxidized in the gas-phase to form sulfuric acid, which could then partition into cloud droplets or aerosol particles. If the aerosol particles were to activate, then this could subsequently lead to cloud droplet acidification. Alternatively, if exhaust were directly emitted into the cloud, then gas-phase $\mathrm{SO}_{2}$ could partition into the cloud droplet and undergo aqueous-phase processing. The correla- tion with below-cloud sulfate suggests that enhanced sulfur emissions led to an decrease in $\mathrm{pH}$. Even more suggestive of ship-influenced acidification is the correlation between cloud water vanadium and cloud water acidity $\left(R^{2}=0.8\right.$, Fig. 8). Studies have shown that shipping emissions are the predominant source of vanadium in the marine atmosphere (Agrawal et al., 2008; Sholkovitz et al., 2009; Furutani et al., 2011). The strong correlation between vanadium and acidity and the enhancement of both during perturbed conditions implies that in the present study, shipping emissions largely contributed to cloud water acidification.

The variation in iron concentrations with below-cloud sulfate (Fig. 7) could result from a number of sources. While iron is often attributed to continental dust, recent studies suggest that iron also has significant sources from ship emissions. Using single particle mass spectrometry, Furutani et al. (2011) found that iron-containing aerosol from Asian outflows could be subdivided into several major iron-containing categories, one of which is iron associated with vanadium. Iron-containing aerosols constituted nearly $40 \%$ of the total number of particles in the ship-associated vanadium category. While it is possible that shipping emissions enhanced iron concentrations during perturbed flights, it appears that elevated iron concentrations in the present study were largely due to continental dust. Figure 8 (bottom) shows the relationship between iron and manganese in cloud water samples. The strong correlation $\left(R^{2}=0.9\right)$ suggests that the two are linked to a common source.

Manganese is primarily attributed to crustal minerals (Statham and Chester, 1988; Guieu et al., 1994; Ohta et al., 2006; Duvall et al., 2008). Iron and manganese concentrations were not strongly correlated to cloud water sulfate ( $R^{2}=0.27$ and 0.29 for iron and manganese, respectively); therefore, the elevation of iron and manganese in cloud water during perturbed flights is likely indicative of air transported from continental sources. The contribution of belowcloud sulfate from continental sources is difficult to quantify given that iron and manganese are related to the transport of dust and are not directly linked to anthropogenic sources. We note, however, that iron and manganese are not strongly correlated with cloud water acidification (not shown, $R^{2}=0.36$ ) which we hypothesize resulted from $\mathrm{SO}_{2}$ oxidation. Furthermore, we show in Sect. 3.5 that perturbed flights were largely affected by air masses that were transported through major shipping lanes and not by air masses that were transported directly over land. Though we cannot rule out continental sources as contributors to below-cloud sulfate, we presume that shipping emissions exerted a stronger impact on properties of marine aerosol over continental sources given that metals associated with shipping emissions, such as vanadium, are strongly correlated to other properties of cloud water chemistry such as acidification.

DMS as a major source of sulfate during perturbed flights can be ruled out in the measurements here based on the small variation of methanesulfonic acid (MSA, DMS oxidation 


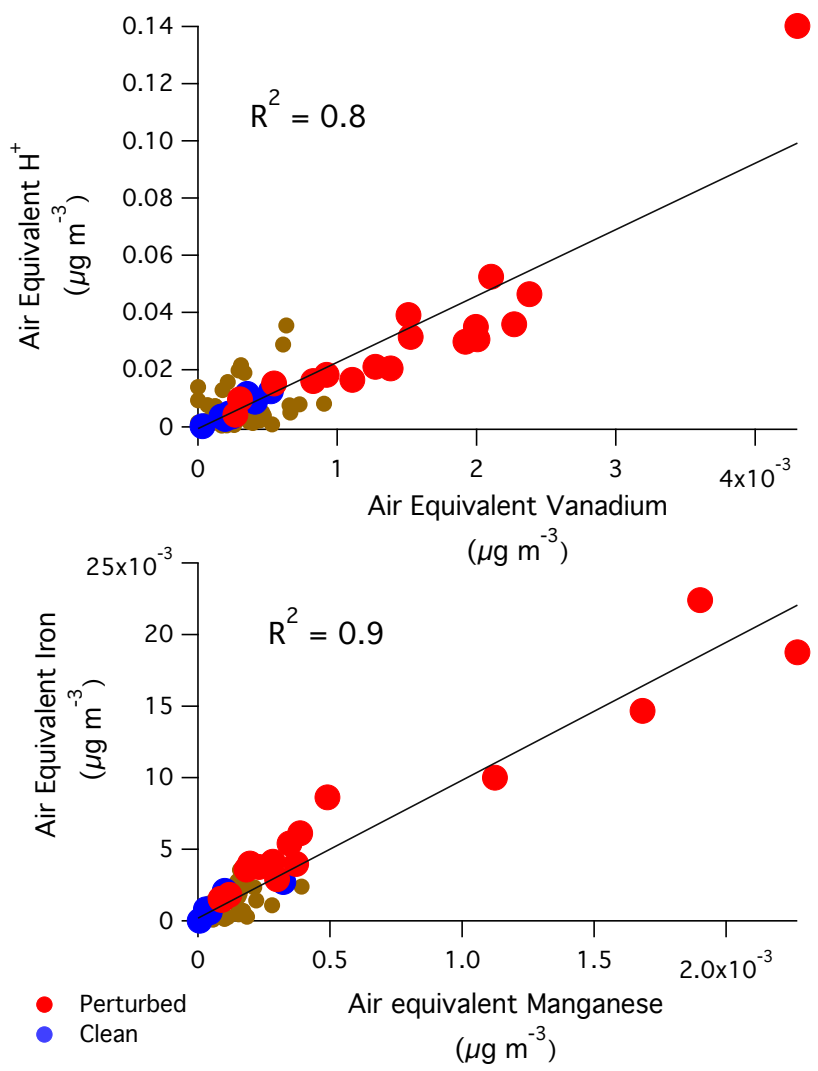

Fig. 8. Top - variation in air equivalent vanadium with respect to air equivalent hydronium concentrations for cloud water samples. Hydronium concentrations were calculated based on cloud water sample $\mathrm{pH}$. Bottom - trend in manganese and iron concentrations in cloud water for measurements made during clean (blue) and perturbed (red) days, respectively.

product). Appendix Fig. A1 shows the variation of cloud water MSA and sulfate as measured by ion chromatography. The amount of MSA in cloud water was no different during perturbed flights when compared to clean or intermediate flights. We infer from these results and those from Figs. 7 and 8 that the primary source of below-cloud sulfate during perturbed flights originated from ship exhaust.

\subsection{Back-trajectory comparisons}

As discussed in Sect. 3.4, the variation of manganese and iron in cloud water samples is likely indicative of crustal minerals transported from continental sources. Based on these results, we presume that the enhancement in sulfate during perturbed flights was at least partly due to changes in meteorology. These inferences are supported by the $72 \mathrm{~h}$ (NOAA HYSPLIT) back-trajectories corresponding to cloud water samples collected during clean and perturbed flights (Fig. 9).

During clean flights, air was primarily transported across the remote ocean, which may explain the observation of low mass loadings in sulfate, organics, iron, and manganese (Ta-

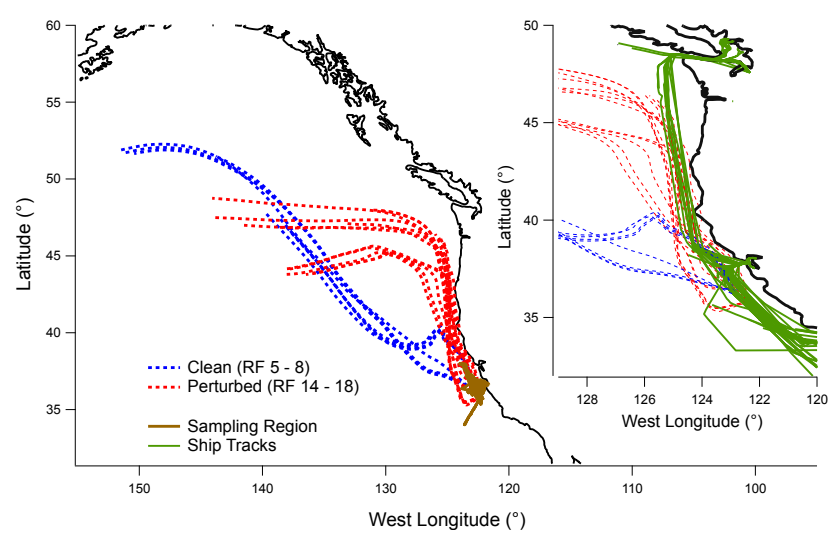

Fig. 9. Back-trajectories (72 h) of cloud water samples collected during clean (blue) and perturbed (red) flights. Back-trajectories were calculated using the NOAA HYSPLIT model (available at: http://www.arl.noaa.gov/ready/hysplit4.html). Simulations were initialized with trajectories ending at the time, location and altitude of cloud water sampling. Inset shows a closer perspective of the California coast. The green traces are the ship tracks of 15 cargo and tanker ships probed during the campaign and illustrate the general location of the shipping lanes north of Long Beach, CA.

ble 3, Fig. 2). During flights in which there is strong evidence of anthropogenic influence, air was primarily transported along the coast and through some of the most heavily transited shipping lanes. This is consistent with the observation of enhanced vanadium (shipping influences), iron, and manganese (continental influence) in cloud water samples during perturbed flights (Figs. 7 and 8). We infer from Fig. 9 that changes in meteorology likely influenced the variation in aerosol and cloud properties and that the enhancement of sulfate below cloud during perturbed conditions is partly due to the transport of air masses through shipping lanes.

\section{Ship impacts on marine aerosol and clouds}

\subsection{Organic aerosol mass spectra}

In the following discussion, we compare organic aerosol spectra during clean and perturbed flights to investigate possible influences of ship emissions on the composition of cloud droplet residuals and dry, below-cloud marine aerosol (Fig. 10). Flight 9 (RF 9) was used as a basis for clean conditions, despite exhibiting slightly higher sulfate than most other flights categorized as clean, because in this flight, distinct ship tracks were observed next to unperturbed cloud. As shown in the column of spectra to the right of the dotted line in Fig. 10, we compare perturbed and unperturbed organic spectra of cloud droplet residuals to provide a reference to how the organic composition of cloud particles changes in the presence of ship emissions. These spectra can be compared to those from flight 15 (RF 15), which was found to have the highest concentrations of vanadium and sulfate 


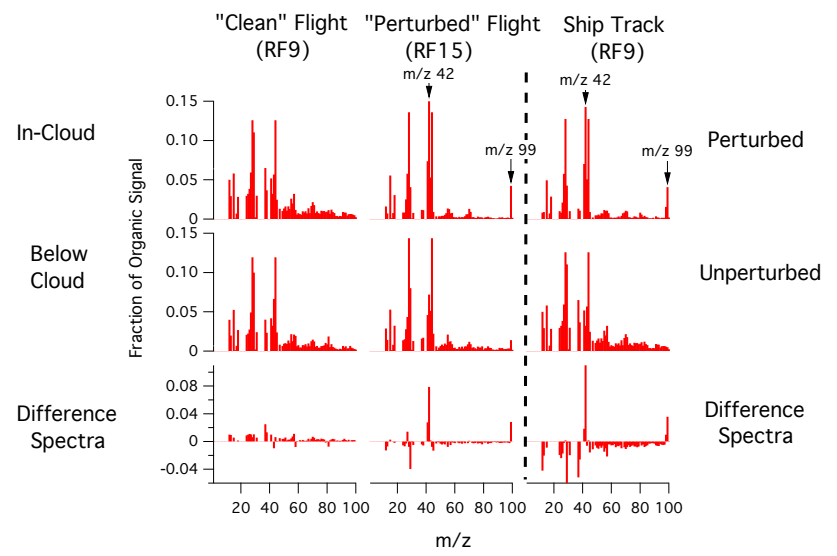

Fig. 10. Aerosol mass spectra comparing the organic signature of aerosol below and within cloud for a clean flight (RF 9) and perturbed flight (RF 15). To the right of the dotted line is a comparison of a ship track in cloud observed during RF 9 to the unperturbed, incloud background organics. The bottom row illustrates normalized difference spectra, which are the differences in the normalized $(\mathrm{m} / \mathrm{z}$ mass/total mass) mass spectra of measurements presented in the top and middle rows. Positive values indicate a relative enhancement in masses observed in the top row spectra whereas negative values indicate a relative enhancement in masses observed in the middle row spectra.

within cloud and was the most likely to have been influenced by ship exhaust.

The top and middle rows in Fig. 10 are normalized organic mass spectra of cloud droplet residuals and dry, below-cloud aerosol, respectively. In general, aerosol and cloud residuals are highly oxidized, exhibiting strong signals at $\mathrm{m} / \mathrm{z}$ $44\left(\mathrm{CO}_{2}^{+}\right)$. These spectra are consistent with marine aerosol measured by Murphy et al. (2009) and Phinney et al. (2006) and cloud droplet residuals measured by Lee et al. (2012). Jimenez et al. (2009) classified aerosol with similar mass spectra as low volatility, highly oxidized secondary organic aerosol (LV-OOA).

Many studies have shown that primary organic aerosol from ship and diesel exhaust exhibit reduced ions consistent with hydrocarbon-like organic aerosol (HOA) (e.g., Canagaratna et al., 2004; Murphy et al., 2009; Phinney et al., 2006). The prominent HOA peaks in fresh ship exhaust $(\mathrm{m} / \mathrm{z}$ $55,57,69,71$, etc.) constitute less than $2 \%$ of the mass in dry aerosol during perturbed flights. Murphy et al. (2009) attributed similar observations to dilution processes by comparing AMS measurements of fresh ship emissions to the organic spectrum of exhaust aged for $60 \mathrm{~min}$. The authors showed that the organic fraction evolved to resemble the surrounding low volatility, unperturbed aerosol - the fraction of $m / z 44$ increased, while prominent HOA masses decreased. The authors note that this aging process could be explained primarily by dilution with unperturbed aerosol, how- ever accumulation of low volatility organics may have also increased the fraction of oxidized mass.

The lack of prominent HOA masses in aged ship exhaust precludes the use of these peaks as tracers for ship emissions. Figure 10, however, provides evidence for a distinctive mass spectrum of ship emissions in perturbed cloud residuals. During RF 9, little difference existed between the organic signatures of cloud residuals and below-cloud aerosol (Fig. 10, bottom). In contrast, during RF 15 , cloud residuals exhibited 8 and $3 \%$ enhancements in masses at $\mathrm{m} / z 42$ and 99 over dry, below-cloud aerosol. This enhancement in $\mathrm{m} / \mathrm{z} 42$ and 99 is also observed between the mass spectra of perturbed and unperturbed clouds (Fig. 10, third column), suggesting that $m / z 42$ and 99 may be linked to cloud-processed ship emissions.

The source of $m / z 42$ and 99 can be further investigated when considering the time series trend of $\mathrm{m} / z 99$ across multiple flights. Figure 11 illustrates the variation of $m / z 99$, LWC, and bulk AMS traces for (1) RF 9 - moderately clean, cloudy (2) RF 16 - perturbed, cloudy (3) RF 27 - moderately clean, no clouds and (4) RF 28 - moderately clean, clouds. Flights RF 27 and RF 28 were additional experiments that were conducted outside the sampling area shown in Fig. 1. These flights were performed along the coastline starting in Monterey Bay and ending near the California/Oregon border. Figure 12 shows the flight paths of RF 27 and RF 28 in relationship to the sampling area shown in Fig. 1. Backtrajectories of samples measured in the middle of each flight show that air was transported from the same direction on both days.

Inspection of Fig. 11 reveals multiple trends consistent with the inferences drawn from Fig. 10. First, we note that the time series of $m / z 99$ varies with bulk AMS traces and is most prominent when measuring ship tracks and perturbed air masses. The time series of $m / z 99$ shows an enhancement in mass when ship tracks are detected (marked, Fig. 11), which is not observed in nearby unperturbed clouds. Also, we see that $m / z 99$ is highly variable both in and out of cloud and is coincident with variations of sulfate during a perturbed flight (RF 16). From these results, we infer that the source of $m / z 99$ is shipping exhaust.

The trends in Fig. 11 also imply that $m / z 99$ is linked to cloud processing. Among the flights presented, RF 27 was the only one performed under clear meteorological conditions. This is evident by the negligible LWC during vertical soundings. In addition, the larger mode in the aerosol size distribution (Fig. 11, top row) peaks at a lower diameter $(77 \mathrm{~nm})$ during clear conditions than during cloudy conditions (180-250 nm). This, along with the low LWC, possibly implies that cloud processing contributed less mass to belowcloud aerosol during RF 27 than other flights. The time series of $m / z 99$ during RF 27 shows little variation over the course of the flight. If we contrast this to RF 28, which was performed during a cloudy day and along a similar flight path (as illustrated in Fig. 12), we see that the variation of $m / z, 99$ 


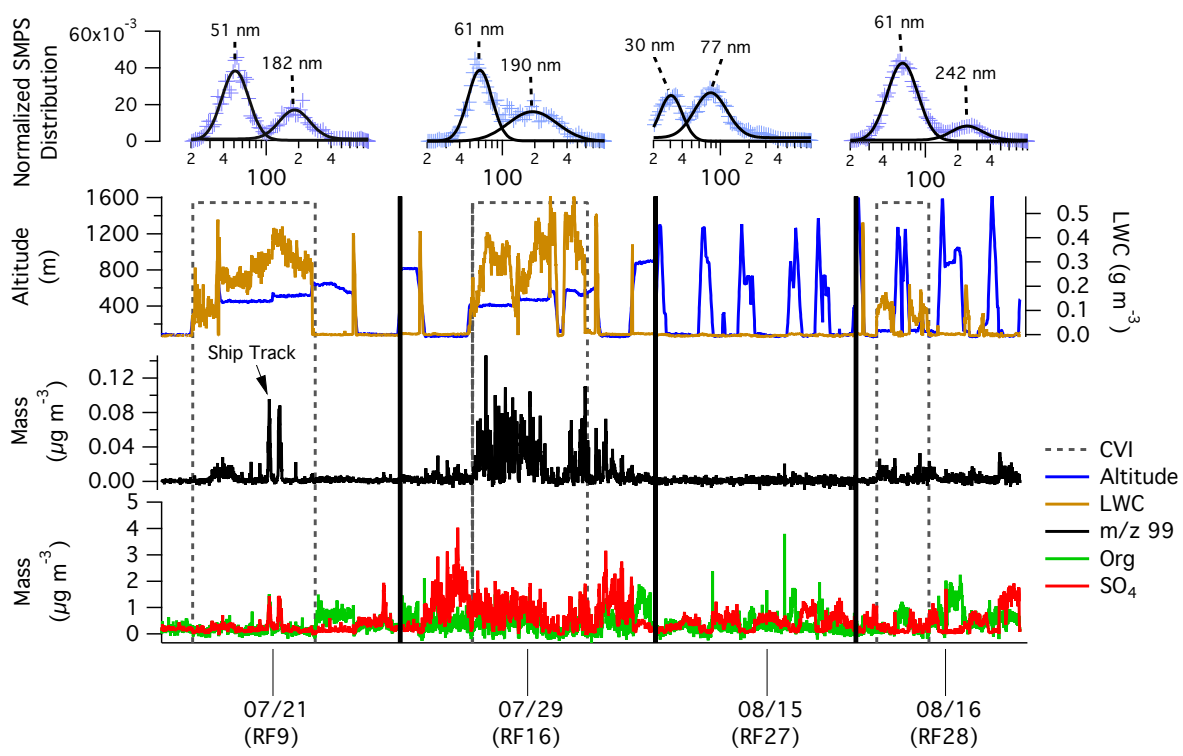

Fig. 11. Time series of organic, sulfate, organic $m / z$, 99, LWC and altitude for research flights RF 9 (moderately clean, clouds), RF 16 (perturbed, clouds), and two additional flights that were performed outside the sampling region defined in Fig. 1, RF 27 (moderately clean, no clouds) and RF 28 (moderately clean, clouds). The top row of normalized aerosol number distributions ( $\left.\mathrm{d} N / \mathrm{d} \log D_{\mathrm{p}} /(\mathrm{integrated} \operatorname{loading})\right)$ show the distribution of marine aerosol below cloud for each flight. The dotted boxes show periods when samples were collected through the CVI inlet.

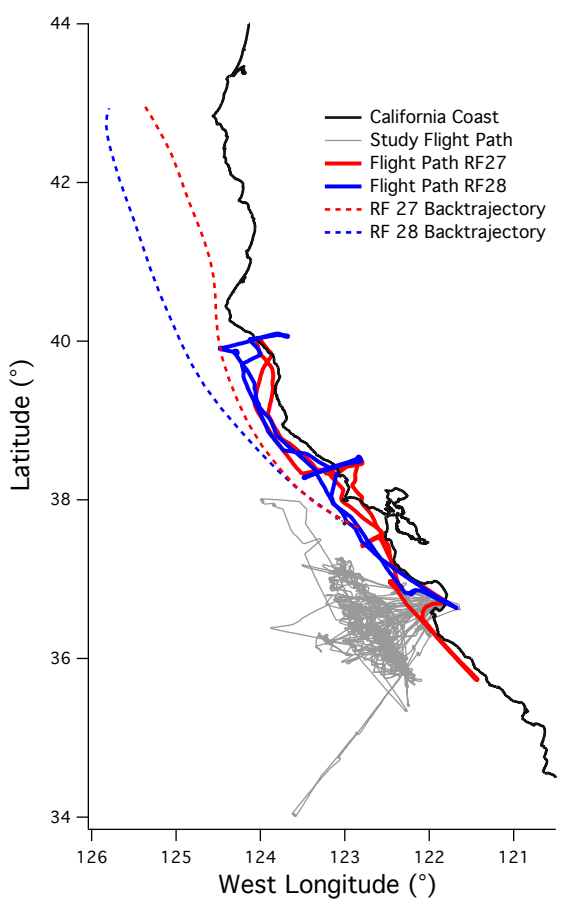

Fig. 12. Path of additional flights RF 27 (red) and RF 28 (blue) compared to the path of all other flights in the present study (grey). Dotted lines are back-trajectories $(24 \mathrm{~h})$ for air masses measured during the middle of each flight. RF 27 and RF 28 were coastal gradient flights conducted on clear (RF 27) and cloudy (RF 28) days. is enhanced in and out of cloud. This evidence, along with the variation of $m / z 99$ in ship-impacted air masses, leads us to conclude that the variation of $m / z 99$ likely results from cloud processing of ship emissions.

\subsection{Application of $m / z 42$ and 99 in evaluating ship-impacted airspace}

Given the unit mass resolution of the C-ToF AMS, a number of masses could be responsible for the signals observed at $m / z 42$ and 99. The species $\mathrm{C}_{2} \mathrm{H}_{2} \mathrm{O}^{+}, \mathrm{C}_{3} \mathrm{H}_{6}^{+}, \mathrm{C}_{2} \mathrm{H}_{4} \mathrm{~N}^{+}$ and $\mathrm{CHOCl}_{2}^{+}$are the non-isotopic ions present at $\mathrm{m} / \mathrm{z} 42$ while $\mathrm{C}_{8} \mathrm{H}_{3}^{+}, \mathrm{C}_{6} \mathrm{H}_{11} \mathrm{O}^{+}, \mathrm{C}_{5} \mathrm{H}_{7} \mathrm{O}_{2}^{+}$and $\mathrm{C}_{7} \mathrm{H}_{15}^{+}$are the nonisotopic ions present at $\mathrm{m} / z$ 99. Thus, the variation of $\mathrm{m} / \mathrm{z}$ 42 and 99 in ship-impacted clouds could result from the fragmentation of aqueous-phase oxidation products $\left(\mathrm{C}_{2} \mathrm{H}_{2} \mathrm{O}^{+}\right.$, $\mathrm{C}_{5} \mathrm{H}_{7} \mathrm{O}_{2}^{+}$, and $\left.\mathrm{C}_{6} \mathrm{H}_{11} \mathrm{O}^{+}\right)$, alkane species $\left(\mathrm{C}_{7} \mathrm{H}_{15}^{+}\right)$or unsaturated carbon chains $\left(\mathrm{C}_{3} \mathrm{H}_{6}^{+}, \mathrm{C}_{8} \mathrm{H}_{3}^{+}\right)$. High-resolution AMS measurements of marine aerosol performed onboard the R/V Point Sur suggests that the enhancements in masses at $\mathrm{m} / \mathrm{z}$ 42 and 99 result from the increase in signal from $\mathrm{C}_{2} \mathrm{H}_{2} \mathrm{O}^{+}$ and $\mathrm{C}_{5} \mathrm{H}_{7} \mathrm{O}_{2}^{+}$(see Sect. 4.3). This supports the presumption that the enhancement of $\mathrm{m} / z, 2$ and 99 in perturbed air masses result from aqueous-phase oxidation of ship emissions. We note that other masses, such as $m / z$ 44, are prominent in the mass spectra of ship emissions measured in-cloud (see Fig. 10). We suspect that these masses also result from cloud-processed ship emissions. However, given that these masses also dominate surrounding unperturbed air masses, 


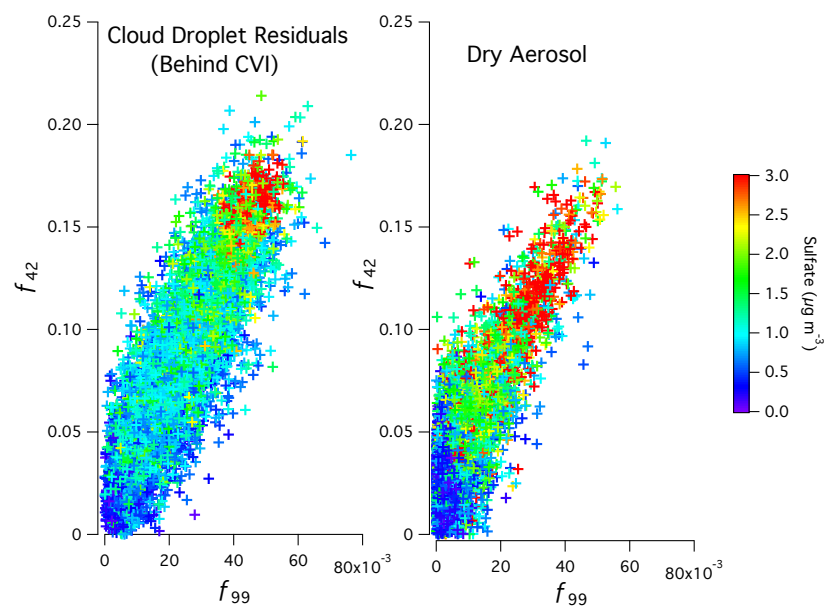

Fig. 13. Variation of the organic fraction of $\mathrm{m} / \mathrm{z}, 42$ and $\mathrm{m} / \mathrm{z}, 99$ $\left(f_{42}, f_{99}\right)$ in the organic spectra of cloud water droplet residuals and dry aerosol. Markers are colored by sulfate loading to illustrate the potential impact of ships on each measurement.

we believe that using $m / z 42$ and 99 as tracers for cloudprocessed ship emissions will help to delineate the source of subsequent marine aerosol measurements.

Given the large fraction of $m / z 42$ and 99 in perturbed air relative to clean air, we propose using these masses to indicate the degree to which shipping emissions affect marine aerosol. Figure 13 shows the relationship between the fractions of $m / z, 42$ and 99 in the present study. Markers are colored by sulfate mass concentrations to illustrate the extent to which ships may have impacted each measurement. These plots show that the fraction of $m / z, 42$ in the organic spectra strongly correlates with the fraction of $m / z 99$, with $R^{2}=0.72$ and 0.67 for measurements of cloud droplet residuals and dry aerosol, respectively. Also, higher fractions of $m / z, 42$ and 99 are coincident with higher loadings of sulfate. Appendix Fig. A2 shows the Pearson $R$ correlation spectrum relating the fraction of $m / z 42$ and 99 with sulfate loading (top) and the fraction of all other organic masses (middle, bottom). Of all the masses in the organic spectrum, $m / z 42$ and 99 have the strongest correlation with sulfate $(R=0.58$ and 0.53 , respectively). This correlation could result from simultaneous aqueous phase sulfur oxidation or from the presence of sulfate in shipping emissions. Similarly, these two ions appear to correlate only with each other and not with typical aerosol tracers (e.g., $m / z 57$ for HOA spectra and $\mathrm{m} / z, 44$ for OOA). The relationship between $\mathrm{m} / z, 42$ and 99 appears to be unique and strongly linked to ship emissions.

If we take the fraction of $\mathrm{m} / z, 42$ and $\mathrm{m} / z$, 99 to reflect the degree of cloud-processed ship emissions (as suggested by Figs. 10 and 11) and that ship emissions are coincident with elevated sulfate concentrations (as suggested by Fig. 7 and the observation of high sulfate during the heaviest ship-influenced flights), then we see that Fig. 13 illustrates the extent to which ship emissions influence marine aerosol. Therefore, we propose a metric by which one can evaluate the extent of ship-impacted air masses in the presence of clouds. Measurements of the organic fractions of $\mathrm{m} / z 42\left(f_{42}\right)$ and $99\left(f_{99}\right)$ scattering about the red markers in Fig. 13 ( $\left.f_{42}>0.15 ; f_{99}>0.04\right)$ would imply heavy influence from shipping emissions. Measurements of $m / z 42$ and 99 scattering about the green markers $\left(0.05<f_{42}<0.15\right.$; $\left.0.01<f_{99}<0.04\right)$ would imply moderate, but persistent, ship influences. Finally, measurements of $\mathrm{m} / z, 42$ and 99 scattering about the blue markers $\left(f_{42}<0.05 ; f_{99}<0.01\right)$ would imply clean, non-ship-influenced air. If we apply these metrics to the data in the present study, this would imply that $72 \%$ of the measurements made behind the CVI and $12 \%$ of measurements of dry aerosol were at least moderately impacted by ship emissions.

Despite observing similar spectra from cloud-processed organics originating from many different ships during the E-PEACE campaign, we note that shipping emissions are highly variable. Thus, one cannot assume that all cloudprocessed shipping emissions will exhibit the same mass spectra as those presented here. Furthermore, we were unable to determine an exact chemical source for the masses at $m / z 42$ and 99 . Therefore, this proposed metric is subject to future identification of the exact source of these masses. We note that further investigations into the chemical origin of $m / z 42$ and 99 might also help to elucidate chemical processes not yet identified in current literature.

\subsection{High resolution AMS analysis of ions at $m / z 42$ and 99}

Additional aerosol properties were measured below cloud onboard the R/V Point Sur from 13-23 July. The R/V Point Sur was primarily deployed to generate controlled ship tracks for aerosol/cloud interaction studies (Russell et al., 2012); however, the high-resolution AMS onboard the R/V Point Sur continuously sampled marine aerosol. As shown in Table 3 and Fig. 2, the first half of the cruise (14-19 July) was coincident with the cleanest period of the study, whereas the latter half of the cruise (20-23 July) corresponded to periods of elevated sulfate. Investigating the variation of ions at $\mathrm{m} / \mathrm{z}, 42$ and 99 during the latter half of the cruise is likely to provide information relevant to ship-impacted air masses.

Table 4 summarizes the fraction of the non-isotopic ions at $\mathrm{m} / z 42$ and 99 during the R/V Point Sur cruise. Over the entire cruise (top), ions $\mathrm{C}_{2} \mathrm{H}_{2} \mathrm{O}^{+}\left(\mathrm{m} / z\right.$ 42) and $\mathrm{C}_{5} \mathrm{H}_{7} \mathrm{O}_{2}^{+}(\mathrm{m} / z$ 99) constitute the majority $(>50 \%)$ of the mass at their respective $m / z$. The contribution of these ions to the total signal increased during the latter half of the cruise. The fraction of other ions either decreased or increased little $(<3 \%)$ during the period of elevated sulfate (bottom), implying that ions at $m / z 42$ and 99 other than $\mathrm{C}_{2} \mathrm{H}_{2} \mathrm{O}^{+}$and $\mathrm{C}_{5} \mathrm{H}_{7} \mathrm{O}_{2}^{+}$are not strongly associated with ship emissions. 
Table 4. Fraction of each ion at $\mathrm{m} / \mathrm{z}, 42$ and $\mathrm{m} / \mathrm{z} 99$ over the entire R/V Point Sur cruise (top) and during periods of high sulfate loading (bottom). Values in parenthesis are the variance in the measurement.

\begin{tabular}{|c|c|c|c|c|c|}
\hline \multicolumn{3}{|c|}{$\begin{array}{c}m / z 42 \\
\text { Average over entire cruise }\end{array}$} & \multicolumn{3}{|c|}{$\begin{array}{c}m / z 99 \\
\text { Average over entire cruise }\end{array}$} \\
\hline Ion & $\begin{array}{l}\text { Fraction of total } \\
\text { organic signal }\end{array}$ & $\begin{array}{l}\text { Fraction of signal } \\
\text { at } m / z 42\end{array}$ & Ion & $\begin{array}{l}\text { Fraction of total } \\
\text { organic signal }\end{array}$ & $\begin{array}{l}\text { Fraction of signal } \\
\text { at } m / z 99\end{array}$ \\
\hline $\mathrm{C}_{2} \mathrm{H}_{2} \mathrm{O}^{+}$ & $\begin{array}{l}0.014 \\
\left(5.11 \times 10^{-5}\right)\end{array}$ & $\begin{array}{l}0.57 \\
(0.030)\end{array}$ & $\mathrm{C}_{5} \mathrm{H}_{7} \mathrm{O}_{2}^{+}$ & $\begin{array}{l}4.22 \times 10^{-4} \\
\left(1.26 \times 10^{-7}\right)\end{array}$ & $\begin{array}{l}0.51 \\
(0.044)\end{array}$ \\
\hline $\mathrm{C}_{3} \mathrm{H}_{6}^{+}$ & $\begin{array}{l}0.008 \\
\left(2.43 \times 10^{-5}\right)\end{array}$ & $\begin{array}{l}0.33 \\
(0.037)\end{array}$ & $\mathrm{C}_{7} \mathrm{H}_{15}^{+}$ & $\begin{array}{l}2.42 \times 10^{-4} \\
\left(5.48 \times 10^{-8}\right)\end{array}$ & $\begin{array}{l}0.21 \\
(0.036)\end{array}$ \\
\hline $\mathrm{C}_{2} \mathrm{H}_{4} \mathrm{~N}^{+}$ & $\begin{array}{l}0.002 \\
\left(2.36 \times 10^{-6}\right)\end{array}$ & $\begin{array}{l}0.08 \\
(0.005)\end{array}$ & $\mathrm{C}_{6} \mathrm{H}_{11} \mathrm{O}^{+}$ & $\begin{array}{l}1.84 \times 10^{-4} \\
\left(2.40 \times 10^{-8}\right)\end{array}$ & $\begin{array}{l}0.19 \\
(0.020)\end{array}$ \\
\hline $\mathrm{CHOCl}_{2}^{+}$ & $\begin{array}{l}4.01 \times 10^{-4} \\
\left(1.26 \times 10^{-7}\right)\end{array}$ & $\begin{array}{l}0.02 \\
(0.0004)\end{array}$ & $\mathrm{C}_{8} \mathrm{H}_{3}^{+}$ & $\begin{array}{l}7.81 \times 10^{-5} \\
\left(9.21 \times 10^{-9}\right)\end{array}$ & $\begin{array}{l}0.09 \\
(0.008)\end{array}$ \\
\hline \multicolumn{3}{|c|}{ Average during period of elevated sulfate (19-23 Jul) } & \multicolumn{3}{|c|}{ Average during period of elevated sulfate (19-23 Jul) } \\
\hline Ion & $\begin{array}{l}\text { Fraction of total } \\
\text { organic signal }\end{array}$ & $\begin{array}{l}\text { Fraction of signal } \\
\text { at } m / z 42\end{array}$ & Ion & $\begin{array}{l}\text { Fraction of total } \\
\text { organic signal }\end{array}$ & $\begin{array}{l}\text { Fraction of signal } \\
\text { at } m / z 99\end{array}$ \\
\hline $\mathrm{C}_{2} \mathrm{H}_{2} \mathrm{O}^{+}$ & $\begin{array}{l}0.020 \\
\left(5.07 \times 10^{-5}\right)\end{array}$ & $\begin{array}{l}0.72 \\
(0.013)\end{array}$ & $\mathrm{C}_{5} \mathrm{H}_{7} \mathrm{O}_{2}^{+}$ & $\begin{array}{l}6.72 \times 10^{-4} \\
\left(1.25 \times 10^{-7}\right)\end{array}$ & $\begin{array}{l}0.58 \\
(0.030)\end{array}$ \\
\hline $\mathrm{C}_{3} \mathrm{H}_{6}^{+}$ & $\begin{array}{l}0.004 \\
\left(8.27 \times 10^{-6}\right)\end{array}$ & $\begin{array}{l}0.15 \\
(0.009)\end{array}$ & $\mathrm{C}_{7} \mathrm{H}_{15}^{+}$ & $\begin{array}{l}2.23 \times 10^{-4} \\
\left(5.11 \times 10^{-8}\right)\end{array}$ & $\begin{array}{l}0.15 \\
(0.023)\end{array}$ \\
\hline $\mathrm{C}_{2} \mathrm{H}_{4} \mathrm{~N}^{+}$ & $\begin{array}{l}0.003 \\
\left(2.51 \times 10^{-6}\right)\end{array}$ & $\begin{array}{l}0.11 \\
(0.006)\end{array}$ & $\mathrm{C}_{6} \mathrm{H}_{11} \mathrm{O}^{+}$ & $\begin{array}{l}2.23 \times 10^{-4} \\
\left(2.78 \times 10^{-8}\right)\end{array}$ & $\begin{array}{l}0.18 \\
(0.013)\end{array}$ \\
\hline $\mathrm{CHOCl}_{2}^{+}$ & $\begin{array}{l}2.92 \times 10^{-4} \\
\left(1.21 \times 10^{-7}\right)\end{array}$ & $\begin{array}{l}0.01 \\
(0.0004)\end{array}$ & $\mathrm{C}_{8} \mathrm{H}_{3}^{+}$ & $\begin{array}{l}1.08 \times 10^{-4} \\
\left(1.17 \times 10^{-8}\right)\end{array}$ & $\begin{array}{l}0.10 \\
(0.007)\end{array}$ \\
\hline
\end{tabular}

Based on Table 4, we presume that $\mathrm{C}_{2} \mathrm{H}_{2} \mathrm{O}^{+}$and $\mathrm{C}_{5} \mathrm{H}_{7} \mathrm{O}_{2}^{+}$ are the major ions responsible for the variation in $\mathrm{m} / z 42$ and 99 observed in Fig. 9. Even though the alkane ion at $m / z 99$ $\left(\mathrm{C}_{7} \mathrm{H}_{15}^{+}\right)$constituted approximately $20 \%$ of the signal, this ion can be ruled out as a major contributor to the variation in $m / z 99$ because other major HOA-type ions $(\mathrm{m} / z$ 55, 57, 69, 71 , etc.) were not observed to vary significantly with $\mathrm{m} / \mathrm{z}$ 42 or 99 (see Appendix Fig. A2). $\mathrm{C}_{3} \mathrm{H}_{6}^{+}$was also variable and constituted a significant fraction of the signal at $m / z 42$. Though the contribution of this ion decreased when averaged during the perturbed period, $\mathrm{C}_{3} \mathrm{H}_{6}^{+}$is an unsaturated, reduced ion of the series $\mathrm{C}_{\mathrm{n}} \mathrm{H}_{2 \mathrm{n}}^{+}$, which is likely alkene in nature (McLafferty, 1980), that could have originated from an HOA or aged organic source.

Appendix Fig. A3 shows the variation in the organic fraction of $\mathrm{C}_{2} \mathrm{H}_{2} \mathrm{O}^{+}$and $\mathrm{C}_{3} \mathrm{H}_{6}^{+}$at $m / z 42$ versus the organic fraction of $\mathrm{C}_{5} \mathrm{H}_{7} \mathrm{O}_{2}^{+}$at $m / z$ 99. Over the entire cruise, $\mathrm{C}_{2} \mathrm{H}_{2} \mathrm{O}^{+}$ is better correlated with $\mathrm{C}_{5} \mathrm{H}_{7} \mathrm{O}_{2}^{+}$than with the reduced ion ( $R^{2}=0.49$ versus $R^{2}=-0.09$, respectively). The two oxidized ions also exhibit a positive correlation that is consistent with the variation of $m / z, 42$ and $m / z 99$ observed in Fig. 13. The variation appears to be coincident with increasing sulfate, which is also similar to the trend observed in Fig. 13. Appendix Fig. A3 also shows the time series trends of each ion at $m / z 42$ and 99 during the clean and perturbed periods. During the clean period, there is little variation in the ions at their respective masses. In contrast, during the periods of inceased sulfate, the variations at $m / z 42$ and 99 are enhanced and are mostly attributable to $\mathrm{C}_{2} \mathrm{H}_{2} \mathrm{O}^{+}$and $\mathrm{C}_{5} \mathrm{H}_{7} \mathrm{O}_{2}^{+}$. In conjunction with Table 5, Fig. A3 suggests that the variations in $m / z \quad 42$ and 99 observed in C-ToF AMS measurements result from the enhancement of the oxidized ions $\mathrm{C}_{2} \mathrm{H}_{2} \mathrm{O}^{+}$and $\mathrm{C}_{5} \mathrm{H}_{7} \mathrm{O}_{2}^{+}$, respectively.

\section{Conclusions}

A major finding of the present work is the identification of aerosol mass spectral peaks at $m / z 42$ and 99 as markers for cloud-processed ship emissions. The co-variation of $m / z$ 42 and 99 in dry marine aerosol is unique and likely due to ship emissions that were processed by clouds and subsequently dried. Based on high-resolution AMS measurements, it appears that these masses were primarily due to variations in oxidized ions. In the present study, we are unable to link the variation of these ions to a specific chemical source. Therefore, until future studies can identify a specific compound that is linked to $m / z 42$ and 99 , we must caution that not all cloud-processed shipping emissions may 


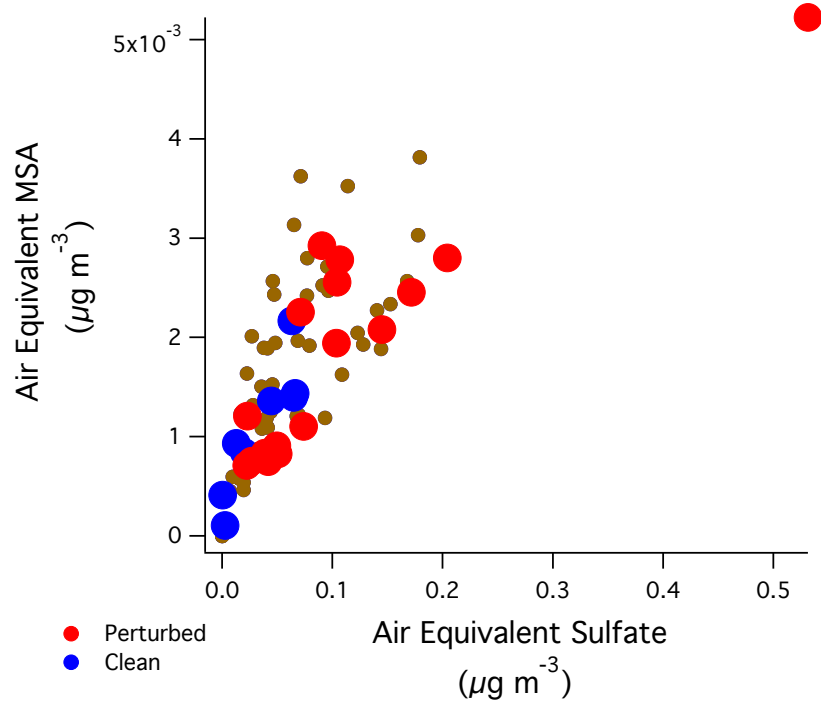

Fig. A1. Variation of air equivalent MSA and sulfate in cloud water droplets. Red markers represent measurements made during perturbed flights (RF 14-18), blue markers represent measurements made during clean flights (RF 5-8). Brown markers are all other measurements.

exhibit enhancements in these ions. Further investigations into the source of these ions may provide information about the chemical transformations of shipping emissions in the marine atmosphere.

Though the exact chemical source remains uncertain, one can use the fractions of $m / z 42$ and $m / z 99$ as a proxy for determining the extent of ship influences on cloud and aerosol properties in the marine environment. Measurements of the organic fractions of $m / z 42\left(f_{42}\right)$ and $99\left(f_{99}\right)$ falling within the range $f_{42}>0.15 ; f_{99}>0.04$ would imply heavy influence from shipping emissions. Measurements of $m / z 42$ and 99 in the range $0.05<f_{42}<0.15 ; 0.01<f_{99}<0.04$ would imply moderate, but persistent influences from ships. Finally, measurements of $\mathrm{m} / z 42$ and 99 in the range $f_{42}<0.05$; $f_{99}<0.01$ would imply clean, non-ship-influenced air. These proxies apply under the condition in which clouds have been impacted by ship emissions. The results from this study also suggest that shipping exhaust is a major contributor to marine aerosol in regions of heavy shipping. If we apply the proposed conditions for moderate shipping influences, we find that $72 \%$ of the measurements illustrated in Fig. 13 are (at least) moderately perturbed cloud particles, while $12 \%$ of the measurements are moderately perturbed evaporated cloud droplets. The marine atmosphere off the coast of Central California is likely seldom free from shipping influences and exhibits a persistent shipping signature on marine particles in the region defined between latitude $35.5-37.5^{\circ} \mathrm{N}$ and longitude $122-123.25^{\circ} \mathrm{W}$.

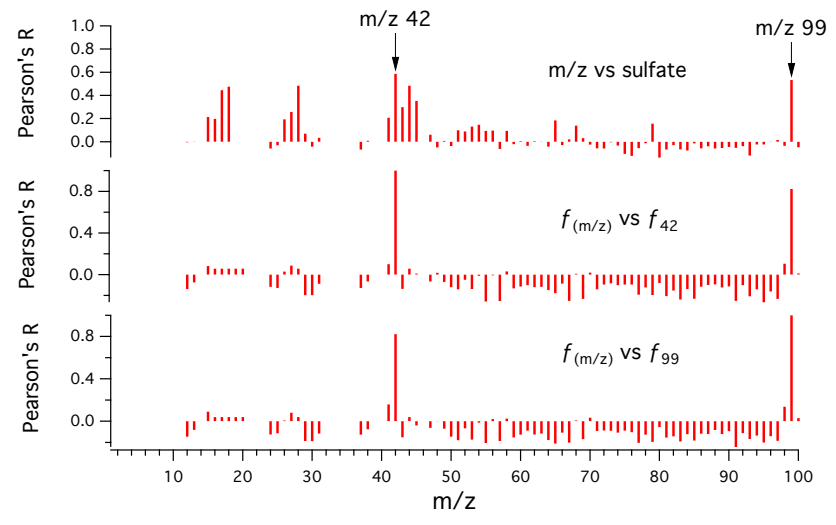

Fig. A2. Pearson $R$ spectrum showing the variation of $m / z$ concentrations vs. the concentration of sulfate (top), the variation of the fraction of $m / z 42\left(f_{42}\right)$ against the fraction of all other organic masses (middle), and the variation of the fraction of $m / z 99\left(f_{99}\right)$ against the fraction of all other organic masses (bottom). These correlations were calculated for measurements made outside of cloud.

\section{Appendix A}

\section{Additional instrument information}

\section{A1 Physical properties of aerosol and cloud droplets}

Cloud and aerosol properties were measured onboard the Twin Otter using a suite of wing-mounted probes and cabinbased size classifiers. Aerosol size and number concentrations were measured outside the aircraft using a passive cavity aerosol spectrometer probe (PCASP) (Particle Measuring Systems, Boulder, CO). Simultaneous measurements were performed behind the main aerosol inlet/CVI using a custombuilt scanning mobility particle sizer (SMPS) consisting of a differential mobility analyzer (DMA, model 3081, TSI) coupled to a condensation particle counter (CPC 3010, TSI, Shoreview, MN). PCASP and SMPS were calibrated using polystyrene latex spheres.

Cloud droplet distributions were measured using a cloud, aerosol and precipitation spectrometer (CAS) (Droplet Measurement Technologies, Boulder, $\mathrm{CO}$ ) and was calibrated using glass beads. Cloud droplet number concentrations presented in this study reflect integrated CAS distributions for particles with diameters $2-50 \mu \mathrm{m}$.

Cloud condensation nuclei $(\mathrm{CCN})$ number concentrations were measured using a streamwise thermal-graident cloud condensation nuclei counter (CCNC, Droplet Measurement Technologies) (Lance et al., 2006; Roberts and Nenes, 2005). A flow orifice and active control system was used to maintain instrument pressure at $700 \mathrm{mb}$ independent of ambient pressure. The instrument was mostly run in scanning flow CCN analysis (SCFA) mode (Moore and Nenes, 2009). SFCA produced CCN spectra over the range $0.15-0.85 \%$ supersaturation every forty seconds. During zig-zag ship intercepts, 

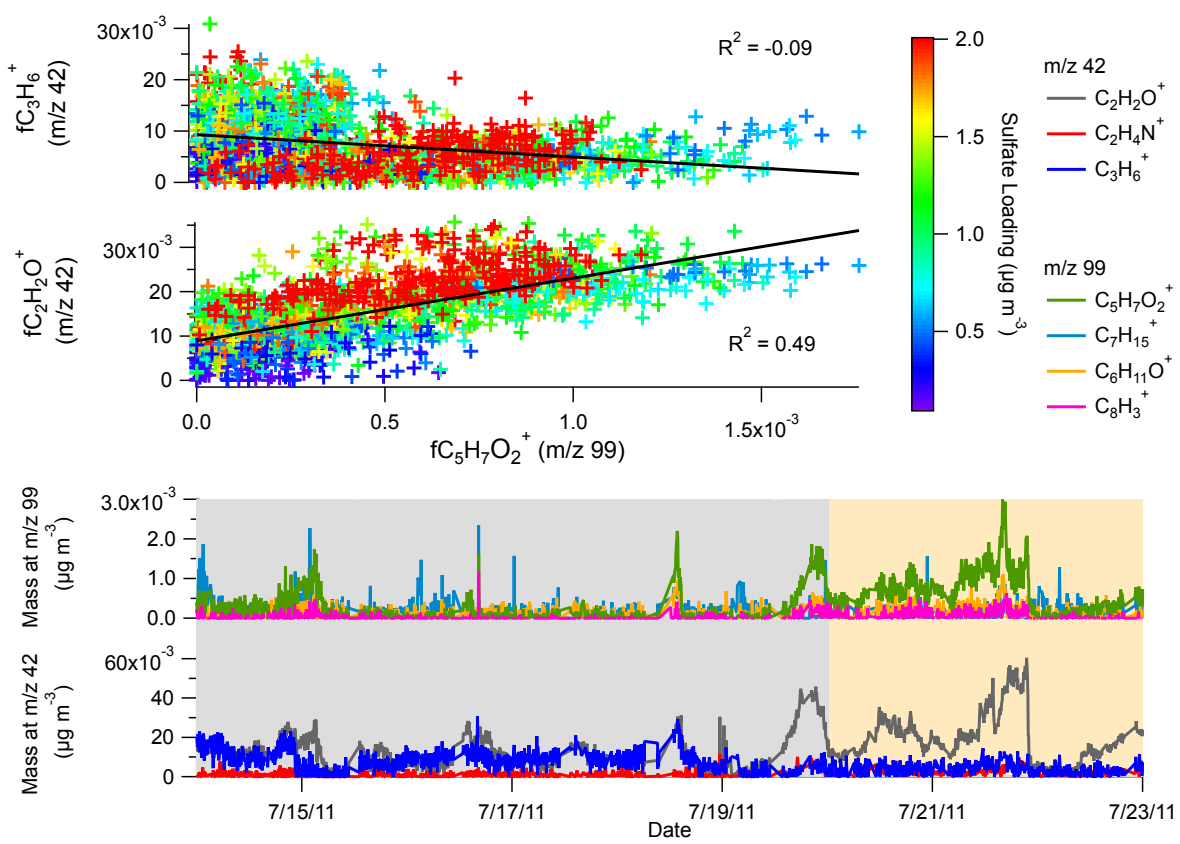

Fig. A3. Top - variation of $\mathrm{C}_{2} \mathrm{H}_{2} \mathrm{O}^{+}$and $\mathrm{C}_{3} \mathrm{H}_{6}^{+}$at $m / z 42$ with $\mathrm{C}_{5} \mathrm{H}_{7} \mathrm{O}_{2}^{+}$at $m / z$ 99. Markers are colored by sulfate loading. Bottom - time series trend showing the variation of the ions at $\mathrm{m} / \mathrm{z} 42$ and 99 . Region shaded grey corresponds to the clean period of the cruise, region shaded light brown corresponds to the perturbed period of cruise.

CCNC operation was switched to conventional operation, maintaining a constant flow rate and constant $0.15 \%$ supersaturation.

\section{A2 Composition measurements by aerosol mass spectrometry}

A compact time-of-flight ( $\mathrm{CToF})$ aerosol mass spectrometer (AMS, Aerodyne Research Inc., Billerica, MA) was used onboard the Twin Otter to measure bulk aerosol chemistry. A high-resolution time-of-flight AMS (HR-ToF-AMS) was used onboard the R/V Point Sur to characterize detailed aerosol chemistry. The AMS has been described elsewhere and only a brief description is given here (Jayne et al., 2000; Allan et al., 2004; Drewnick et al., 2005). The AMS measures the ensemble average mass spectra and chemically resolved size distribution of non-refractory particle phase organic and inorganic species. Spectra were analyzed in IGOR Pro (WaveMetrics, Inc., Lake Oswego, Oregon, USA) using the SQUIRREL v $1.51 \mathrm{H}$ and PIKA v $1.10 \mathrm{H}$ modules. Gas phase interferences were corrected using the fragmentation table developed by Allan et al. (2004) and Aiken et al. (2008).

Onboard the Twin Otter, MS mode was run for $8 \mathrm{~s}$ per saved run. A pressure-controlled inlet was used to maintain a flow rate of $1.4 \mathrm{~cm}^{-3} \mathrm{~s}^{-1}$ to the AMS vacuum chamber. Prior to each flight, the AMS ionization efficiency (the ratio of the number of molecules ionized to the total number of molecules that enter the instrument) was calibrated using dried $350 \mathrm{~nm} \mathrm{NH} \mathrm{NO}_{3}$ particles. Detection limits were taken to be twice the standard deviation of organic, sulfate, nitrate, ammonium and total mass measured during the filter period.

Composition dependent collection efficiencies (CE) were calculated based on the method by Middlebrook et al. (2012). Figure A4 compares aerosol mass concentrations measured by AMS to calculated aerosol mass concentrations from SMPS data before (left) and after (right) applying the CE correction factor. Volume concentrations measured by the SMPS were calculated by integrating SMPS data from $60-1000 \mathrm{~nm}$. Volume concentrations were then converted to mass concentrations assuming a density of $1.6 \mathrm{~g} \mathrm{~cm}^{-3}$, which is representative of a mixture of $60 \%$ sulfuric acid $\left(\rho=1.84 \mathrm{~g} \mathrm{~cm}^{-3}\right)$ and $40 \%$ organics $\left(\rho=1.2 \mathrm{~g} \mathrm{~cm}^{-3}\right)$ (Phinney et al., 2006). Before applying the CE correction, AMS and SMPS data scatter below the $1: 1$ line with a slope of 0.45 . After applying the CE correction, AMS and SMPS data scatter close to the $1: 1$ line with a slope of 0.85 . The bias towards higher aerosol mass concentrations calculated from SMPS data may result from a number of unknowns including overestimation of aerosol density, uncertainty of particle losses in the SMPS instrument and uncertainty in the amount of non-refractory material present in the aerosol. In general, however, the good agreement warrants use of the method developed by Middlebrook et al. (2012) in estimating the CE correction factor.

\section{A3 Cloud water chemistry}

Cloud water samples were collected using a modified Mohen slotted cloudwater collector (Hegg and Hobbs, 1986). 


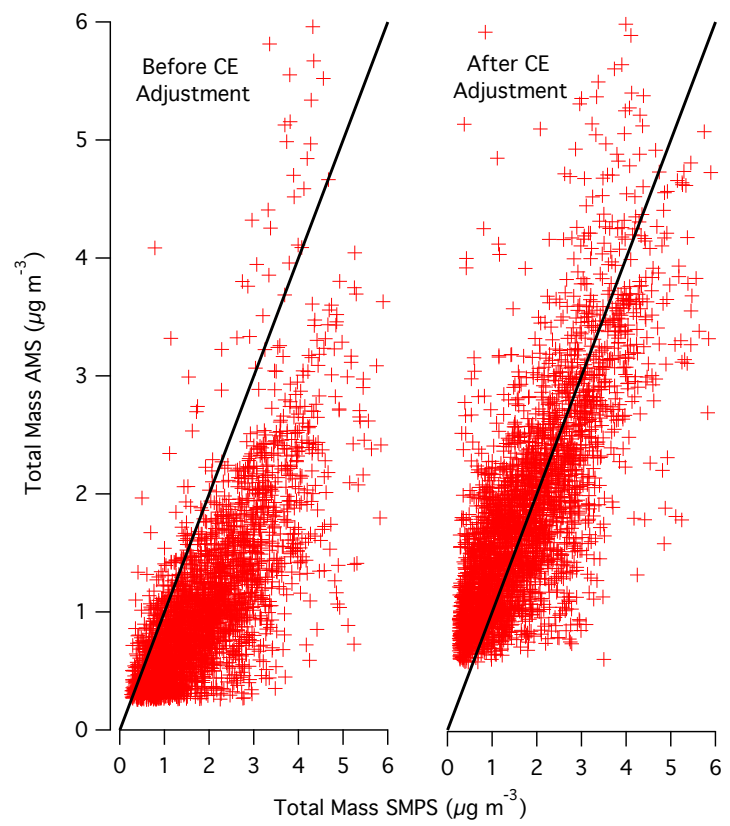

Fig. A4. Comparison of collection efficiency (CE) corrected AMS mass measurements to calculated total mass measured by SMPS. The plot on the left is the trend before CE correction (slope $=0.45$ ), the plot on the right is the trend after CE correction (slope $=0.85$ ). Volume concentration measured by SMPS was converted to mass concentration assuming a density of $1.6 \mathrm{~g} \mathrm{~cm}^{-3}$, which is representative of a mixture of $60 \%$ sulfuric acid $\left(\rho=1.84 \mathrm{~g} \mathrm{~cm}^{-3}\right)$ and $40 \%$ organics $\left(\rho=1.2 \mathrm{~g} \mathrm{~cm}^{-3}\right)$ (Phinney et al., 2006).

Samples were collected at various altitudes and stored at $4{ }^{\circ} \mathrm{C}$ until chemical analysis could be performed. Trace metals were measured using inductively coupled plasma mass spectrometry (ICP-MS) and major ions were measured using ion chromatography (IC).

To compare cloud water chemistry measured by off-line analysis to below-cloud aerosol loading measured by AMS, cloud water sample concentrations (ppb) were converted to air equivalent concentrations $\left(\mu \mathrm{g} \mathrm{m}^{-3}\right)$ as prescribed by (Straub et al., 2007). To achieve this conversion, the ion concentrations measured by ICP-MS and IC were multiplied by the average LWC recorded during sample collection. Measurements reported in air equivalent units reflect the total amount of material present per volume of air.

Acknowledgements. This work was funded by ONR grants N00014-11-1-0783, N00014-10-1-0200, and N00014-10-1-0811, and NSF grants AGS-1013381 and AGS-1008848. We acknowledge Dean Hegg for providing the cloud water collector.

Edited by: R. Krejci

\section{References}

Ackerman, A. S., Toon, O. B., and Hobbs, P. V.: Numerical modeling of ship tracks produced by injections of cloud condensation nuclei into marine stratiform clouds, J. Geophys. Res., 100, 7121-7133, 1995.

Agrawal, H., Malloy, Q. G. J., Welch, W. A., Wayne Miller, J., and Cocker III, D. R.: In-use gaseous and particulate matter emissions from a modern ocean going container vessel, Atmos. Environ., 42, 5504-5510, 2008.

Aiken, A. C., DeCarlo, P. F., Kroll, J. H., Worsnop, D. R., Huffman, J. A., Docherty, K. S., Ulbrich, I. M., Mohr, C., Kimmel, J. R., Sueper, D., Sun, Y., Zhang, Q., Trimborn, A., Northway, M., Ziemann, P. J., Canagaratna, M. R., Onasch, T. B., Alfarra, M. R., Prevot, A. S. H., Dommen, J., Duplissy, J., Metzger, A., Baltensperger, U., and Jimenez, J. L.: O/C and OM/OC ratios of primary, secondary, and ambient organic aerosols with high-resolution time-of-flight aerosol mass spectrometry, Environ. Sci. Technol., 42, 4478-4485, 2008.

Allan, J., Delia, A., Coe, H., Bower, K., Alfarra, M., Jimenez, J., Middlebrook, A., Drewnick, F., Onasch, T., and Canagaratna, M.: A generalised method for the extraction of chemically resolved mass spectra from aerodyne aerosol mass spectrometer data, J. Aerosol Sci., 35, 909-922, 2004.

Benedict, K. B., Lee, T., and Collett Jr., J. L.: Cloud water composition over the Southeastern Pacific Ocean during the VOCALS regional experiment, Atmos. Environ., 46, 104-114, 2012.

Bilde, M. and Svenningsson, B.:CCN activation of slightly soluble organics: the importance of small amounts of inorganic salt and particle phase, Tellus, 56B, 128-134, 2004.

Canagaratna, M. R., Jayne, J. T., Ghertner, D. A., Herndon, S., Shi, Q., Jimenez, J. L., Silva, P. J., Williams, P., Lanni, T., Drewnick, F., Demerjian, K. L., Kolb, C. E., and Worsnop, D. R.: Chase studies of particulate emissions from in-use New York City vehicles, Aerosol Sci. Tech., 38, 555-573, 2004.

Christensen, M. W. and Stephens, G. L.: Microphysical and macrophysical responses of marine stratocumulus polluted by underlying ships: Evidence of cloud deepening, J. Geophys. Res., 116, D03201, doi:10.1029/2010JD014638, 2011.

Coakley, J., Bernstein, R., and Durkee, P.: Effect of ship-stack effluents on cloud reflectivity, Science, 237, 1020-1022, 1987.

Corbett, J. J. and Fischbeck, P.: Emissions from ships, Science, 278, 823-824, 1997.

Cunningham, W. C. and Zoller, W. H.: The chemical composition of remote aerosols, J. Aerosol Sci., 12, 367-384, 1981.

Drewnick, F., Hings, S., DeCarlo, P., Jayne, J., Gonin, M., Fuhrer, K., Weimer, S., Jimenez, J., Demerjian, K., Borrmann, S., and Worsnop, D.: A new Time-Of-Flight Aerosol Mass Spectrometer (TOF-AMS) - instrument description and first field deployment, Aerosol Sci. Tech., 39, 637-658, 2005.

Durkee, P. A., Noone, K. J., and Bluth, R. T.: The Monterey area ship track experiment, J. Atmos. Sci., 57, 2523-2541, 2000.

Duvall, R. M., Majestic, B. J., Shafer, M. M., Chuang, P. Y., Simoneit, B. R. T., and Schauer, J. J.: The water-soluble fraction of carbon, sulfur, and crustal elements in Asian aerosols and Asian soils, Atmos. Environ., 42, 5872-5884, 2008.

Eyring, V., Kohler, H., van Aardenne, J., and Lauer, A.: Emissions from international shipping: 1. The last 50 years, J. Geophys. Res., 110, D17305, doi:10.1029/2004JD005619, 2005. 
Ervens, B., Gligorovski, S. and Herrmann, H.:Temperaturedependent rate constants for hydroxyl radical reactions with organic compounds in aqueous solutions, Phys. Chem. Chem. Phys., 5, 1811-1824, 2003a.

Ervens, B., George, C., Williams, J.E., Buxton, G.V., Salmon, G.A., Bydder, M., Wilkinson, F., Dentener, F., Mirabel, P., Wolke, R., Herrmann, H.:CAPRAM 2.4 (MODAC mechanism): An extended and condensed tropospheric aqueous phase mechanism and its application, J. Geophys. Res., 108, 4426, doi:10.1029/2002JD002202, 2003b.

Faloona, I.: Sulfur processing in the marine atmospheric boundary layer: A review and critical assessment of modeling uncertainties, Atmos. Environ., 43, 2841-2854, 2009.

Frick, G. and Hoppel, W.: Airship measurements of ship's exhaust plumes and their effect on marine boundary layer clouds, J. Atmos. Sci., 57, 2625-2648, 2000.

Furutani, H., Jung, J., Miura, K., Takami, A., Kato, S., Kajii, Y., and Uematsu, M.: Single-particle chemical characterization and source apportionment of iron-containing atmospheric aerosols in Asian outflow, J. Geophys. Res., 116, D18204, doi:10.1029/2011JD015867, 2011.

Guieu, C., Duce, R., and Arimoto, R.: Dissolved input of manganese to the ocean: Aerosol source, J. Geophys. Res., 99, 18789-18800, 1994.

Hegg, D. A. and Hobbs, P. V.: Sulfate and nitrate chemistry in cumuliform clouds, Atmos. Environ., 20, 901-909, 1986.

Hegg, D. A., Covert, D. S., Rood, M. J., and Hobbs, P. V.: Measurements of aerosol optical properties in marine air, J. Geophys. Res., 101, 12893-12903, 1996.

Hegg, D.A., Covert, D.S., Jonsson, H., Covert, P.A.: Determination of the Transmission Efficiency of an Aircraft Aerosol Inlet, Aerosol Sci. Technol., 39, 966-971, 2005.

Hegg, D. A., Covert, D. S., and Jonsson, H. H.: Measurements of size-resolved hygroscopicity in the California coastal zone, Atmos. Chem. Phys., 8, 7193-7203, doi:10.5194/acp-8-7193-2008, 2008.

Hegg, D. A., Covert, D., Jonsson, H., and Woods, R.: Differentiating natural and anthropogenic cloud condensation nuclei in the California coastal zone, Tellus B, 61, 669-676, 2009.

Hegg, D. A., Covert, D. S., Jonsson, H. H., and Woods, R. K.: The contribution of anthropogenic aerosols to aerosol light-scattering and CCN activity in the California coastal zone, Atmos. Chem. Phys., 10, 7341-7351, doi:10.5194/acp-10-7341-2010, 2010.

Hersey, S. P., Sorooshian, A., Murphy, S. M., Flagan, R. C., and Seinfeld, J. H.: Aerosol hygroscopicity in the marine atmosphere: a closure study using high-time-resolution, multiple-RH DASHSP and size-resolved C-ToF-AMS data, Atmos. Chem. Phys., 9, 2543-2554, doi:10.5194/acp-9-2543-2009, 2009.

Hoppel, W., Frick, G., and Larson, R.: Effect of nonprecipitating clouds on the aerosol size distribution in the marine boundary layer, Geophys. Res. Lett., 13, 125-128, 1986.

Hoppel, W., Frick, G., and Fitzgerald, J.: Marine boundary layer measurements of new particle formation and the effects nonprecipitating clouds have on aerosol size distribution, J. Geophys. Res., 99, 14443-14459, 1994.

Hudson, J. G., Garrett, T. J., Hobbs, P. V., Strader, S. R., Xie, Y., and Yum, S. S.: Cloud Condensation Nuclei and Ship Tracks, J. Atmos. Sci., 57, 2696-2706, 2000.
Jayne, J. T., Leard, D. C., Zhang, X., Davidovits, P., Smith, K. A., Kolb, C. E., and Worsnop, D. R.: Development of an aerosol mass spectrometer for size and composition analysis of submicron particles, Aerosol Sci. Tech., 33, 49-70, 2000.

Jimenez, J. L.,Canagaratna, M. R., Donahue, N. M.,Prévôt, A. S. H., Zhang, Q., Kroll, J. H., DeCarlo, P. F., Allan, J. D., Coe, H., Ng, N. L., Aiken, A. C., Docherty, K. S., Ulbrich, I. M., Grieshop, A. P., Robinson, A. L., Duplissy, J., Smith, J. D., Wilson, K. R., Lanz, V. A., Hueglin, C., Sun, Y. L., Tian, J., Laaksonen, A., Raatikainen, T., Rautiainen, J., Vaattovaara, P., Ehn, M., Kulmala, M., Tomlinson, J. M., Collins, D. R., Cubison, M. J., Dunlea, J., Huffman, J. A., Onasch, T. B., Alfarra, M. R., Williams, P. I., Bower, K., Kondo, Y., Schneider, J., Drewnick, F., Borrmann, S., Weimer, S., Demerjian, K., Salcedo, D., Cottrell, L., Griffin, R., Takami, A., Miyoshi, T., Hatakeyama, S. Shimono, A., Sun, J. Y., Zhang, Y. M., Dzepina, K., Kimmel, J. R., Sueper, D., Jayne, J. T., Herndon, S. C., Trimborn, A. M., Williams, L. R., Wood, E. C., Middlebrook, A. M., Kolb, C. E., Baltensperger, U., and Worsnop, D. R.:Evolution of Organic Aerosols in the Atmosphere, Science, 326, 1525-1529, 2009.

Katoshevski, D., Nenes, A., and Seinfeld, J. H.:A study of processes that govern the maintenance of aerosols in the marine boundary layer, J. Aerosol Sci., 30, 503-532, 1999.

Kazil, J., Wang, H., Feingold, G., Clarke, A. D., Snider, J. R., and Bandy, A. R.: Modeling chemical and aerosol processes in the transition from closed to open cells during VOCALS-REx, Atmos. Chem. Phys., 11, 7491-7514, doi:10.5194/acp-11-74912011, 2011.

Lance, S., Nenes, A., Medina, J., and Smith, J. N.: Mapping the operation of the DMT continuous flow CCN counter, Aerosol Sci. Techol., 40, 242-254, 2006.

Langley, L., Leaitch, W. R., Lohmann, U., Shantz, N. C., and Worsnop, D. R.: Contributions from DMS and ship emissions to CCN observed over the summertime North Pacific, Atmos. Chem. Phys., 10, 1287-1314, doi:10.5194/acp-10-1287-2010, 2010.

Lee, A. K. Y., Hayden, K. L., Herckes, P., Leaitch, W. R., Liggio, J., Macdonald, A. M., and Abbatt, J. P. D.: Characterization of aerosol and cloud water at a mountain site during WACS 2010: secondary organic aerosol formation through oxidative cloud processing, Atmos. Chem. Phys. Discuss., 12, 6019-6047, doi:10.5194/acpd-12-6019-2012, 2012.

Lu, M.-L., Sorooshian, A., Jonsson, H. H., Feingold, G., Flagan, R. C., and Seinfeld, J. H.: Marine stratocumulus aerosolcloud relationships in the MASE-II experiment: Precipitation susceptibility in Eastern Pacific marine stratocumulus, J. Geophys. Res., 114, D24203, doi:10.1029/2009JD012774, 2009.

McInnes, L., Quinn, P., Covert, D., and Anderson, T.: Gravimetric analysis, ionic composition, and associated water mass of the marine aerosol, Atmos. Environ., 30, 869-884, 1996.

McInnes, L., Covert, D., and Baker, B.: The number of sea-salt, sulfate, and carbonaceous particles in the marine atmosphere, Tellus, 49, 300-313, 1997.

McLafferty, F.: Interpretation of Mass Spectra, University Science Books, 3rd Edn., 1980.

Middlebrook, A. M., Bahreini, R., Jimenez, J. L., and Canagaratna, M. R.: Evaluation of composition-dependent collection efficiencies for the aerodyne aerosol mass spectrometer using 
field data, Aerosol Sci. Tech., 46, 258-271, 2012.

Moore, R. H. and Nenes, A.: Scanning flow CCN analysis - a method for fast measurements of CCN spectra, Aerosol Sci. Techol., 43, 1192-1207, 2009.

Moore, R. H., Bahreini, R., Brock, C. A., Froyd, K. D., Cozic, J., Holloway, J. S., Middlebrook, A. M., Murphy, D. M., and Nenes, A.: Hygroscopicity and composition of Alaskan Arctic CCN during April 2008, Atmos. Chem. Phys., 11, 11807-11825, doi:10.5194/acp-11-11807-2011, 2011.

Moore, R. H., Cerully, K., Bahreini, R., Brock, C. A., Middlebrook, A. M., and Nenes, A.: Hygroscopicity and composition of California CCN during summer 2010, J. Geophys. Res., 117, D00V12, doi:10.1029/2011JD017352, 2012.

Murphy, S. M., Agrawal, H., Sorooshian, A., Padró, L. T., Gates, H., Hersey, S., Welch, W. A., Jung, H., Miller, J. W., Cocker III, D. R., Nenes, A., Jonsson, H. H., Flagan, R. C., and Seinfeld, J. H.: Comprehensive simultaneous shipboard and airborne characterization of exhaust from a modern container ship at sea, Environ. Sci. Technol., 43, 4626-4640, 2009.

Noone, K., Ostrom, E., Ferek, R., Garrett, T., Hobbs, P., Johnson, D., Taylor, J., Russell, L., Flagan, R., Seinfeld, J. H., O'Dowd, C., Smith, M., Durkee, P., Nielsen, K., Hudson, J., Pockalny, R., De Bock, L., Van Grieken, R., Gasparovic, R., and Brooks, I.: A case study of ships forming and not forming tracks in moderately polluted clouds, Am. Meterol. Soc., 57, 27292747, 2000.

Ohta, A., Tsuno, H., Kagi, H., Kanai, Y., Nomura, M., Zhang, R., and Terashima, S.: Chemical compositions and XANES speciations of $\mathrm{Fe}, \mathrm{Mn}$ and $\mathrm{Zn}$ from aerosols collected in China and Japan during dust events, Geochem. J., 40, 363-376, 2006.

Ovadnevaite, J., O’Dowd, C., Dall'Osto, M., Ceburnis, D., Worsnop, D.R., and Berresheim, H.: Detecting high contributions of primary organic matter to marine aerosol: A case study, Geophys. Res. Lett., 38, L02807, doi:10.1029/2010GL046083, 2011.

Phinney, L., Richard Leaitch, W., Lohmann, U., Boudries, H., Worsnop, D. R., Jayne, J. T., Toom-Sauntry, D., Wadleigh, M., Sharma, S., and Shantz, N.: Characterization of the aerosol over the sub-arctic North East Pacific Ocean, Deep-Sea Res. Pt. II, 53, 2410-2433, 2006.

Roberts, G. C. and Nenes, A.: A continuous-flow streamwise thermal-gradient $\mathrm{CCN}$ chamber for atmospheric measurements, Aerosol Sci. Techol., 39, 206-221, 2005.

Russell, L. M., Sorooshian, A., Seinfeld, J. H., Albrecht, B. A., Nenes, A., Ahlm, L., Chen, Y.-C., Coggon, M. M., Craven, J. S., Flagan, R. C., Frossard, A. A., Jonsson, H., Jung, E., Lin, J. J., Metcalf, A. R., Modini, R., Mulmenstadt, J., Roberts, G. C., Shingler, T., Song, S., Wang, Z., and Wonaschutz, A.: Eastern Pacific Emitted Aerosol Cloud Experiment (E-PEACE), B. Am. Meteorol. Soc., in press, 2012.
Shingler, T., Dey, S., Sorooshian, A., Brechtel, F. J., Wang, Z., Metcalf, A., Coggon, M., Mülmenstädt, J., Russell, L. M., Jonsson, H. H., and Seinfeld, J. H.: Characterisation and airborne deployment of a new counterflow virtual impactor inlet, Atmos. Meas. Tech., 5, 1259-1269, doi:10.5194/amt-5-1259-2012, 2012.

Sholkovitz, E. R., Sedwick, P. N., and Church, T. M.: Influence of anthropogenic combustion emissions on the deposition of soluble aerosol iron to the ocean: Empirical estimates for island sites in the North Atlantic, Geochim. Cosmochim. Ac., 73, 3981-4003, 2009.

Sorooshian, A., Lu, M.-L., Brechtel, F. J., Jonsson, H., Feingold, G., Flagan, R. C., and Seinfeld, J. H.: On the Source of Organic Acid Aerosol Layers above Clouds, Environ. Sci. Technol., 41, 46474654, 2007a.

Sorooshian, A., Ng, N. L., Chan, A. W. H., Feingold, G., Flagan, R. C., and Seinfeld, J. H.: Particulate organic acids and overall water-soluble aerosol composition measurements from the 2006 Gulf of Mexico Atmospheric Composition and Climate Study (GoMACCS), J. Geophys. Res., 112, D13201, doi:10.1029/2007JD008537, 2007b.

Sorooshian, A., Padró, L. T., Nenes, A., Feingold, G., McComiskey, A., Hersey, S. P., Gates, H., Jonsson, H. H., Miller, S. D., Stephens, G. L., Flagan, R. C., and Seinfeld, J. H.: On the link between ocean biota emissions, aerosol, and maritime clouds: Airborne, ground, and satellite measurements off the coast of California, Global Biogeochem. Cy., 23, GB4007, doi:10.1029/2009GB003464, 2009.

Statham, P. and Chester, R.: Dissolution of manganese from marine atmospheric particulates into seawater and rainwater, Geochim. Cosmochim. Ac., 52, 2433-2437, 1988.

Straub, D. J., Lee, T., and Collett Jr., J. L.: Chemical composition of marine stratocumulus clouds over the Eastern Pacific Ocean, J Geophys. Res., 112, D04307, doi:10.1029/2006JD007439, 2007.

Ulbrich, I. M., Canagaratna, M. R., Zhang, Q., Worsnop, D. R., and Jimenez, J. L.: Interpretation of organic components from Positive Matrix Factorization of aerosol mass spectrometric data, Atmos. Chem. Phys., 9, 2891-2918, doi:10.5194/acp-9-2891-2009, 2009.

Yan, F., Winijkul, E., Jung, S., Bond, T. C., and Streets, D. G.: Global emission projections of particulate matter (PM): I. Exhaust emissions from on-road vehicles, Atmos. Environ., 45, 4830-4844, 2011. 